Southern Methodist University

SMU Scholar

Faculty Journal Articles and Book Chapters

Faculty Scholarship

2017

\title{
Will the Public Service Loan Forgiveness Program Ever Forgive Any Loans?
}

Gregory S. Crespi

Southern Methodist University, Dedman School of Law

\section{Recommended Citation}

Gregory S. Crespi, Will the Public Service Loan Forgiveness Program Ever Forgive Any Loans? (2017)

This document is brought to you for free and open access by the Faculty Scholarship at SMU Scholar. It has been accepted for inclusion in Faculty Journal Articles and Book Chapters by an authorized administrator of SMU Scholar. For more information, please visit http://digitalrepository.smu.edu. 


\title{
WILL THE PUBLIC SERVICE LOAN FORGIVENESS PROGRAM EVER FORGIVE ANY LOANS?
}

\author{
by \\ Gregory Crespi ${ }^{1}$
}

Preliminary Draft

July 29, 2017 


\begin{abstract}
There is a sharp tension between the expectations that hundreds of thousands to millions of persons have regarding their right to eventually have their student loan debts forgiven under the Public Service Loan Forgiveness program, starting this fall, and the legitimate public concerns regarding the large future costs and regressive incidence of the PSLF program's benefits. The Trump Administration has recently proposed prospectively abolishing the PSLF program for future Direct Loans. Whether or not this proposal is adopted, given the large costs of the program (which I estimate will eventually rise to $\$ 12$ billion/year or more as an estimated 200,000 people/year or more will eventually seek debt forgiveness), and given the skewed incidence of its benefits in favor of mid-career doctors and lawyers, I think that there will eventually be a more aggressive push by the Administration or members of Congress for retroactive elimination of the program, or at least for a retroactive tax law amendment to include this forgiven debt as taxable income under IRS Code Section 108 as is now done for debts forgiven under the other income-based loan forgiveness plans.
\end{abstract}

As a matter of positive law this article considers several contractual arguments as well as a couple of Constitutional arguments that opponents of such retroactive statutes could offer. The contractual arguments include an express loan 
terms argument, an implied covenant of good faith and fair dealing-based argument, a promissory estoppel argument, and an unconscionability argument. Some of these arguments against retroactive PSLF program repeal have considerable merit, at least for some Direct Loan borrowers who can make certain fact-specific showings. The Constitutional arguments include the substantive due process issue that would presented by a tax law change that would have retroactive impacts extending back a decade or more. Opponents of such tax legislation might be able to get some traction on the substantive due process issue under Bowen $\mathrm{v}$. POSSE (1986). They also can offer a plausible Takings Clause argument against a tax law change if the courts take the (unlikely) step of regarding the PSLF program's tax exemption for forgiven debt as a contractual commitment, rather than as only a revocable privilege.

Apart from this legal analysis the article does not take a strong normative position on these issues. I do, however, suggest that as a matter of policy a compromise that would arguably fairly balance the interests at issue here may be to continue the PSLF program, but also to retroactively repeal the tax exemption for forgiven debt so as to recapture approximately one-quarter to one-third of the benefits of debt forgiveness, and do so in a modestly progressive manner. Such a compromise should probably also include some provision for spreading the 
payment of those taxes over at least several years in order to avoid unduly burdening these persons with a "tax bomb" effect. 
TABLE OF CONTENTS

I. INTRODUCTION

II. THE DIRECT LOAN MASTER PROMISSORY NOTE

III. THE AMOUNT OF DEBT LIKELY TO BE FORGIVEN UNDER

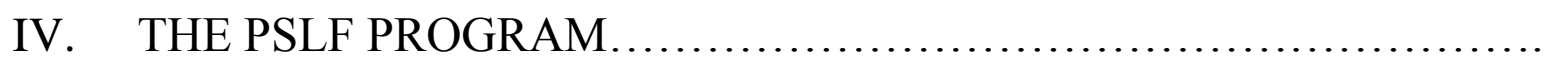

V. BORROWER CONTRACTUAL RIGHTS TO INVOKE DEBT FORGIVENESS AND TAX EXEMPTION OF FORGIVEN DEBT.....
A. The Express Contractual Terms Argument.
B. The Implied Covenant of Good Faith and Fair Dealing Argument.......
C. The Promissory Estoppel Arument.
D. The Unconscionability Argument

VI. FEDERAL GOVERNMENT POWER TO RETROACTIVELY LIMIT PSLF DEBT FORGIVENESS AND TAX TREATMENT PRIVILEGES

VII. CONCLUSION 


\section{INTRODUCTION}

Starting in October of 2017 people are going to start qualifying for taxexempt forgiveness of their remaining federal Direct Loan student debt under the Public Service Loan Forgiveness program ("PSLF program") after 10 years of public service employment. I estimate below in Part III of this article that eventually 200,000 or more Direct Loan borrowers will qualify for and seek debt forgiveness each year under this program.

But this anticipated large-scale debt forgiveness may not actually take place. As I will estimate below in Part III the program's annual cost to taxpayers could be eventually grow to $\$ 12$ billion to $\$ 18$ billion/year, a very large sum, and its benefits would be highly skewed in favor of mid-career doctors and lawyers with large student loan debts. Recognizing these significant cost and distributional concerns the Obama Administration proposed in 2016 to sharply limit the amount of debt that could be forgiven under the program, a proposal that was not enacted into law. The Trump Administration has now in its first budget proposal called for prospective elimination of the PSLF program for future Direct Loans. 
Whether or not this Trump Administration proposal is adopted, given the program's very large projected costs and controversial distribution of benefits, features which will become much more visible once substantial debts start being forgiven on a large scale, there will surely be serious efforts made by the Trump Administration (or a later Administration) or members of Congress to take even more aggressive action and retroactively repeal the PSLF program with regard to all persons who have not yet been granted debt forgiveness. If this occurs it will be very disappointing if not financially devastating to the hundreds of thousands to perhaps millions of persons who will not yet have qualified for debt forgiveness by completing 10 years of public service, but who have relied on the availability of eventual debt forgiveness in making their borrowing and subsequent employment decisions.

But these people may have some legal recourse against the implementation of such retroactive legislation if it is signed into law. There are a number of contractual or Constitutional arguments that can be made against retroactive repeal of the PSLF program, or against retroactive elimination of the current tax exemption for debt forgiven under that program. This article will consider those arguments in some detail. 
My overall conclusion is that it is unclear whether any of those arguments against retroactive legislation would be successful. As a matter of positive law I believe that several of the legal arguments against retroactive repeal of the PSLF program do have considerable merit, and one or more of those arguments may be accepted by the courts, at least for a relatively small subset of some Direct Loan borrowers. In contrast, while several legal arguments against retroactive repeal of the tax exemption for debt forgiven under that program can also be made, and they are not specious arguments, they are much less convincing and are unlikely to prevail against such a statute.

As a matter of social policy, I think that it is a close and difficult question as to whether a retroactive repeal of the PSLF program, or a removal of the tax exemption for debt forgiven under that program, is justified. On the one hand, hundreds of thousands of indebted graduates over the past decade have relied, at least in part, on the prospects of debt forgiveness after 10 years in deciding to take these loans, and in then deciding to accept public service positions that often pay relatively modest compensation. The PSLF program has clearly been successful in encouraging people to choose public service careers, one of its primary objectives. 
On the other hand, as I will later demonstrate, the program will soon become very expensive. The annual costs of this program may soon reach $\$ 12$ billion to $\$ 18$ billion/year, a substantial sum, and in addition the benefits of that program will be decidedly regressive in their incidence, heavily skewed towards mid-career doctors and lawyers.

I do not have strong views or any special insights as to how this tension should be resolved. If one seeks a "middle ground" here to try to address these conflicting concerns, rather than embracing one pole or the other of the debate, in my opinion the best balance may be either a either a continuation of the program, or instead a prospective-only repeal as suggested by the Trump Administration, either one accompanied by a repeal of the tax exemption for forgiven debt under this program so that approximately one-quarter to one-third or more of the benefits of forgiveness will be immediately recaptured in federal or state income tax revenues. These new taxes would be imposed in a somewhat progressive manner, given the structure of marginal tax rates, and given that higher-debt borrowers will in general have higher incomes in the year of forgiveness. This is the general approach taken under all of the other federal income-based loan repayment programs, with their 20- or 25-year loan repayment periods before debt forgiveness 
is granted, and with the taxation of forgiven debt recognized in the year of forgiveness, and this approach may make sense for the PSLF program as well.

If this approach is followed, however, some provision should be made to allow persons to pay these taxes over at least several years so as to avoid unduly burdening these persons having debts forgiven with a "tax bomb" effect due to the imposition of a potentially very large tax obligation without any funds being provided to pay those taxes.

The PLSF program ${ }^{2}$ was enacted in 2007 and went into effect on October 1 of that year. ${ }^{3}$ Under this program a person who has borrowed money for educational purposes through a federal Direct Loan, ${ }^{4}$ and who after October 1, 2007 works for a total of 120 months (which need not be consecutive) ${ }^{5}$ in a qualified public service job, ${ }^{6}$ and also makes regular monthly loan repayments under a qualifying loan repayment plan, ${ }^{7}$ will at the end of that 10 -year period of qualifying employment be entitled to forgiveness of any remaining principal and interest balance outstanding on those Direct Loans. ${ }^{8}$ Moreover, that forgiven debt will not be regarded as taxable cancellation of indebtedness income, unlike the 
manner in which forgiven debt is treated under the several other federal incomebased student loan repayment programs that provide for debt forgiveness. ${ }^{9}$ The Department of Education ("DOE”) has subsequently adopted regulations implementing the PSLF program. ${ }^{10}$

A few people may meet the 10-year employment requirement and qualify for debt forgiveness under this program as early as October of 2017. In 2018 and thereafter, however, the number of people qualifying for and obtaining debt forgiveness will surely grow very substantially. ${ }^{11}$ That is, unless the Trump $\underline{\text { Administration (or a later Administration) and Congress go beyond the }}$ Administration's current proposal to prospectively abolish the PSLF program and instead enact a statute which will deny loan forgiveness not only to future borrowers but also to those persons who have previously taken out Direct Loans and accepted public service employment in reliance on being able to later utilize the program's generous debt forgiveness provisions and the accompanying tax exemption for forgiven debt. ${ }^{12}$

The Trump Administration's May 22, 2017 budget proposal tersely states that "the Budget eliminates the Public Service Loan Forgiveness program,"13 but 
then later states that "All student loan proposals apply to loans originated on or After July 1, 2018, except those provided to borrowers to finish their current course of study." ${ }^{\prime 14}$ This proposal therefore would apply only prospectively to future Direct Loans taken out after that date, and would even retain PSLF program debt forgiveness eligibility for those post-July 1, 2018 Direct Loans that were taken out by persons completing a course of study that was commenced before that date. ${ }^{15}$ Direct Loan borrowers would therefore continue to be eligible for PSLF program debt forgiveness for any pre-July 1, 2018 loans (and for some post-July 1, 2018 loans) once they met the 10-year public service employment requirement. Under this proposal the number of persons obtaining PSLF program debt forgiveness annually, which will rise rapidly starting in 2018, would begin to decline very rapidly after 2028 , eventually dwindling to close to zero by a few years after that date.

As I will later demonstrate in Part III of this article, however, the cost to taxpayers of continuing to provide debt forgiveness to existing Direct Loan borrowers under the current PSLF debt forgiveness terms, and with the current favorable tax treatment of that forgiven debt, may quickly rise in 2018 and afterwords to as much $\$ 12$ billion to $\$ 18$ billion/year. This is a much larger sum 
than most policymakers have so far expected or that the media has discussed. The Trump Administration (or a later Administration) and Congress will surely be strongly tempted to draft (or later amend) any statutory prospective curtailment of the PSLF program to also retroactively apply to existing Direct Loan debts in order to avoid a decade of such a substantial drain on the Treasury, probably totaling well over $\$ 100$ billion between 2017 and 2028. ${ }^{16}$ There will surely be strong political resistance to adopting such a harsh retroactive measure that would take away PSLF program debt forgiveness privileges from existing borrowers. If that resistance proves insurmountable those persons who favor such action may decide to instead propose a statutory change to the Internal Revenue Service Code that would also have retroactive impacts in that the Code would then treat debt forgiven under the PSLF program as taxable cancellation of indebtedness income, in the same manner as will be debts forgiven under each of the several other federal income-based student loan programs, thus recapturing approximately one-quarter to one-third of this forgiven debt in federal or state income tax payments. ${ }^{17}$

But would a statute that goes beyond the current Trump Administration proposal and retroactively curtails or even eliminates the PSLF program's debt forgiveness privileges for existing Direct Loan borrowers, or which changes the 
tax treatment of debts forgiven under this program for existing Direct Loan borrowers, be given legal effect by the courts? Or would those debt forgiveness and tax treatment privileges each be regarded by the courts as contractual obligations of the federal government, and moreover as contractual obligations that cannot not be legally abrogated by statute given Constitutional limitations? These are the questions that I will consider in this article.

There is no provision under the PSLF program for persons to formally enroll in the program prior to filing their application seeking debt forgiveness, and this application cannot be filed until they can document that they have met the required 10-year period of qualifying public service employment. Moreover, the DOE has not yet made available the application form that people will need to file, starting in October of 2017, once those persons begin to qualify for debt forgiveness. The DOE in 2012 did implement a voluntary certification procedure through which prospective applicants may have annual periods of employment certified as qualifying public service employment, prior to their later filing an application for debt forgiveness once they have met the 10 -year employment requirement. ${ }^{18}$ Over half a million borrowers have already availed themselves of this certification procedure even though there is no requirement that persons obtain such prior 
certification in advance of their application for debt forgiveness. ${ }^{19}$ The number of new borrowers obtaining such certifications each year has been growing rapidly in recent years, with 218,223 persons first receiving an employment certification in $2016,{ }^{20}$ a sharp $52.3 \%$ increase over the 143,276 people who first did so in $2015,{ }^{21}$ and over a $100 \%$ increase over the 108,437 people who first did so in $2014 .^{22}$

The fact that people are not required to give the DOE prior notice of their intent to utilize the PSLF program before they later seek to obtain debt forgiveness means that any advance estimates of how many people will actually seek debt forgiveness, and how large the amounts of debt forgiven will be, both individually and in the aggregate, are necessarily highly speculative since at this time no one has yet qualified to apply. As I have noted, a substantial and rapidly growing number of borrowers have indicated their interest in the program by obtaining one or more of the voluntary annual employment certifications, ${ }^{23}$ but this number bears no necessary relationship to the number of people who will eventually qualify for and apply for debt forgiveness.

The initial number of applicants for debt forgiveness in late-2017 is likely to be quite small, only including those Direct Loan borrowers who have held 
qualifying public service employment every year since late-2007 when the PSLF program was first adopted. But it is certain that the number of people applying for debt forgiveness will grow rapidly in 2018 and thereafter as increasing numbers of borrowers become more aware of the program's generous debt forgiveness provisions, as they surely will once it becomes widely publicized that many people are taking great advantage of those provisions, and as they also begin to meet the 10-year public service employment period requirement. Since it has been estimated that roughly one-quarter of all jobs qualify as public service jobs under the PSLF program's very broad definition, ${ }^{24}$ by the time the program reaches roughly a "steady state" in terms of the number of people who seek debt forgiveness each year this number could become quite large, perhaps in the neighborhood of 200,000 people each year if not more. ${ }^{25}$ Given that many of these people will have very substantial amounts of debt forgiven, ${ }^{26}$ in particular many law school graduates ${ }^{27}$ and medical school graduates, ${ }^{28}$ the annual cost to the Treasury of this program could easily grow to a multi-billion dollar sum, ${ }^{29}$ as I will demonstrate in Part III of this article.

Increasing public attention will surely be paid to the large taxpayer costs of the program once significant numbers of people begin to apply for and obtain 
forgiveness of six-figure debts that in some instances will exceed $\$ 200,000$. The Trump Administration's recent proposal to prospectively abolish the PSLF program that was noted above may not be adopted, and even if it is adopted in its current form it will not have retroactive impacts. But whether that proposal is adopted or rejected, in either case it is likely that in coming years, as the major budgetary implications of forgiving this much debt become more clear, other attempts will be made by members of Congress and/or the Trump Administration (or a later Administration) to statutorily limit PSLF program eligibility or its generosity in a retroactive manner, or statutorily limit or eliminate the current exclusion of debt forgiven under this program from taxation.

As greater public attention is paid to the PSLF program there may also be calls made for its elimination, or at least its curtailment or substantial modification, based not upon its overall costs but instead upon the skewed and regressive manner in which its benefits will be conferred. A typical undergraduate borrower who leaves school with a \$30,000 Direct Loan debt, and who then takes a public service job of the nature and compensation level usually available to a person with only an undergraduate degree, and who then enrolls in the popular Pay As You Earn ("PAYE") income-based loan repayment plan, will have on the order of $\$ 25,000$ or 
so of remaining debt to be forgiven after 10 years of public service employment. ${ }^{30}$ For such a borrower the annualized value of the eventual debt forgiveness is approximately equal to an additional $\$ 2,642 /$ year in before-tax income for that 10 year period. ${ }^{31}$ This benefit provides a significant though modest inducement to enter public service that is approximately equivalent to roughly $6 \%$ of additional salary, each year for 10 years, over the average initial public service compensation for persons with only undergraduate degrees. ${ }^{32}$

In sharp contrast, a typical law school graduate who leaves school with a now-common combined undergraduate and law school Direct Loan debt of $\$ 150,000$, and who then enrolls in the PAYE plan and takes a public service position of the sort and compensation level open to recent law school graduates, will experience pronounced negative amortization of his loan debt during the next 10 years and will likely eventually have as much or more than $\$ 200,000$ of debt forgiven, almost an order of magnitude more forgiven debt than will have the typical undergraduate borrower. ${ }^{33}$ Having $\$ 200,000$ of debt forgiven after 10 years is approximately equivalent to receiving an additional $\$ 21,142 /$ year in before-tax income each year for that 10 -year period,$^{34}$ providing a much stronger inducement to enter public service that is approximately equivalent to $38 \%$ of additional salary, 
each year over 10 years, over the average initial public service compensation for law graduates each year. ${ }^{35}$ A typical medical school graduate who also graduates with a $\$ 150,000$ loan debt, and who as is common then spends the next seven years in modestly paid residencies and internships before taking a public service position as a fully licensed doctor, will also experience pronounced negative amortization for most of the 10 years of public service, and will also have on the order of $\$ 200,000$ of debt forgiven. ${ }^{36}$ This is again a benefit roughly equal to $\$ 21,142 /$ year in additional before-tax compensation each year for 10 years. The PSLF program has already come under harsh criticism for this regressive distributional feature and for distorting borrowing incentives even though no debts have yet been forgiven. ${ }^{37}$

The PSLF program could without question be prospectively limited or even terminated by statute with regard to those persons who have not yet taken out any Direct Loans at the time of legislative amendment, as the current Trump Administration proposal calls for. Those persons who have not yet executed any Direct Loan contracts at the time of a statutory amendment that curtailed PSLF program debt forgiveness rights would clearly not be able to utilize the program to obtain forgiveness of later Direct Loan obligations beyond what forgiveness was permitted by that amendment, if any. Nor would those persons who had previously 
taken out Direct Loans have a right to insist upon taking advantage of the preamendment PSLF program terms for any new Direct Loans that they may take out after such an amendment.

The more difficult question that I would like to consider in this article is whether such statutory PSLF program limitations or abolition, or tax law changes limiting or removing the exemption of forgiven debt from income, could also be retroactively imposed upon those persons who have not yet filed an application for PSLF program debt forgiveness after 10 years of qualifying public service employment, but whose loan documentation for at least one of their post-October 1, 2007 Direct Loans was executed prior to the effective date of that new legislation, given that this loan documentation includes references to the PSLF program as a debt forgiveness option that they will have at that time. ${ }^{38}$

Answering this question will require two difficult determinations. First of all, do Direct Loan borrowers have contractual rights under their loan agreements to utilize the current PSLF program debt forgiveness terms and the current favorable tax treatment of that forgiven debt for the loans they have taken out prior to any later legislative amendments that would change those terms? Second, if 
they do have those contractual rights to debt forgiveness and favorable tax treatment of forgiven debt, is the federal government Constitutionally permitted to retroactively abrogate those contractual rights through legislative amendments without providing compensation to those borrowers?

As to the first of these questions, the question as to whether Direct Loan borrowers have contractual rights both to utilize the current PSLF program debt forgiveness terms and to have forgiven debt receive the current favorable tax treatment, I will consider several related legal theories. One or more of these theories may adequately support a claim made by at least some of those persons who have taken out at least one post-October 1, 2007 Direct Loan to finance their education, prior to the effective date of any new legislation limiting or eliminating the PSLF program or altering the current favorable tax treatment of debts that will be forgiven under that program, that they have a contractual right to debt forgiveness in accordance with the PSLF program terms, and if so perhaps also a contractual right to invoke the tax laws that were in force at the time that they took out their loan, at least for those post-October 1, 2007 Direct Loans taken out prior to the effective date of any legislation that may abrogate one or both of those rights for future loans. As to the second of these questions, assuming for the sake of 
argument that the Direct Loan agreements do establish one or both of these borrower contractual rights under one or more legal theories, I will then consider whether the federal government has the power to legislatively abrogate one or both of those rights without providing compensation.

The central loan document executed by borrowers under the federal Direct Loan program is titled the "Master Promissory Note, Direct Subsidized Loans and Direct Unsubsidized Loans, William D. Ford Federal Direct Loan Program”39 ("MPN"). That document provides the basis for each of four separate legal theories that I will consider as to why the execution of this document by a borrower creates a contractual obligation on the part of the government to provide that borrower with current PSLF program debt forgiveness rights, and perhaps also the right to current tax law treatment.

The first legal theory that I will consider will be the argument that the federal government, by making a Direct Loan to a borrower using loan documentation that refers to the PSLF program in the way that the MPN used since October 1, 2007 does, expressly provides that borrower with a contractual right to utilize the existing PSLF program debt forgiveness terms, and also to utilize the 
current exemption from taxation provided for debts forgiven through this program. ${ }^{40}$ This will be argued to be the case even if the PSLF program is later legislatively altered in some fashion, and the loan documentation accordingly revised, with regard to future Direct Loans taken out by that borrower or by future borrowers, or if the relevant debt forgiveness-related tax laws are later changed.

The second and related theory that I will consider is the argument that even if the Direct Loan MPN documentation executed for post-October 1, 2007 loans is interpreted to not expressly provide borrowers with the contractual right to later invoke the PSLF program debt forgiveness terms and tax laws that existed at the time that they took out their loans, those borrowers under accepted contract law principles will still have an implied covenant of good faith and fair dealing included as part of their loan contracts. This implied covenant will arguably protect their reasonable expectations of being able to invoke those PSLF program debt forgiveness terms and the tax exemption for forgiven debt stemming from those Direct Loans taken out before any later legislative abridgement of those rights has become effective and embodied in a revised MPN.

The third argument that I will examine will be the theory that even if those 
post-October 1, 2007 Direct Loan borrowers do not have a right, under either the express contractual terms of the MPN or under the implied covenant of good faith and fair dealing, to avail themselves of the PSLF program debt forgiveness terms that existed when they took out their loans if the program is later legislatively altered so as to terminate those debt forgiveness privileges, or to avail themselves of the current favorable tax treatment of forgiven debt if the IRS Code is later altered so as to eliminate the exemption of forgiven debt from taxation, they nevertheless do have a right to insist upon those favorable debt forgiveness and tax treatment terms under the expansive and widely embraced promissory estoppel theory of contractual liability, based upon the forseeable reliance of those borrowers upon the terms of their loan agreements.

Finally, I will consider the argument that even if the MPN's express and implied terms are interpreted to retroactively subject Direct Loan borrowers to later-enacted legislative changes in the PSLF program, or in the applicable tax laws, and if any promissory estoppel arguments limiting the government's rights to impose those changes are also rejected, those MPN terms that allow such unilateral imposition of harsher repayment terms or tax treatment are unconscionable and should therefore be excised from the loan agreements, thus creating contractual 
rights for pre-legislation borrowers that might protect them from these legislative changes.

Having examined these different theories as to why Direct Loans may create borrower contractual rights to PSLF program debt forgiveness and favorable tax treatment, I will then turn to consider the merits of the arguments that the federal government might offer as to why they should under the Constitution be permitted to retroactively abolish the PSLF program, or to terminate the favorable tax treatment of debts forgiven under that program, without providing compensation, even if those borrowers are determined to have these contractual rights, and especially if they do not have such contractual rights.

This article focuses solely upon the circumstances of post-October 1, 2007 Direct Loan borrowers with regard to subsequent statutory amendments that purport to retroactively curtail their PSLF program debt forgiveness privilege or the tax law treatment debt so forgiven. I will not consider in this article possible attempts by the DOE to impose tighter limits on PSLF program eligibility by adopting more restrictive new regulations that would narrow the scope of eligible public service employment under the existing statutes, rather than by statutory amendment. I will also not consider in this article possible DOE actions that 
would attempt to limit program eligibility through embracing a more restrictive interpretation of the current eligibility regulations. Some recent DOE actions of this latter nature were taken in 2016 by the Obama Administration, and are currently being challenged in court by the American Bar Association, ${ }^{41}$ and I am examining the merits of these challenges in a separate article. ${ }^{42}$

I will present in Part II of this article the text of the relevant PSLF programrelated language that has been included since October 1, 2007 in the MPN for Direct Loan transactions. In Part III I will explain why it is not yet possible to offer with confidence precise estimates of the individual and aggregate amounts of loan debt that may possibly be forgiven under this program over the coming decades. I will also, however, conduct a realistic hypothetical calculation based on the best data available that will strongly suggest that the amount of debt forgiven under the PSLF program will eventually grow to as much as $\$ 12$ billion per year, and perhaps to as much as $\$ 18$ billion/year, imposing very substantial costs upon taxpayers. I will then discuss in Part IV each of these several contractual theories that I have noted above that could be invoked by Direct Loan borrowers, on the basis of the current MPN language and on the basis of various theories of contractual liability, in an attempt to establish that they have a contractual right to 
later utilize the current PSLF program debt forgiveness terms, and to have any debt later forgiven given the currently favorable tax treatment.

In Part V I will first consider the legality of the retroactive abolition of the PSLF program, and of the retroactive repeal tax exemption for any debt forgiven under this program, if Direct Loan borrower are determined to not have contractual rights to debt forgiveness and favorable tax treatment. I will then consider in Part $\mathrm{V}$ the legality of the imposition of retroactive legislation under the assumption that Direct Loan borrowers do have contractual rights to PSLF program debt forgiveness and the current favorable tax treatment of debt so forgiven under one or another of the contractual theories I have set forth. I will here assess the arguments that can be offered for and against the federal government having the right to retroactively abrogate this contractual right to debt forgiveness, and/or the contractual right to have forgiven debt exempt from taxation, without providing compensation to affected borrowers.. Part VI of the article will present my overall conclusions.

Let me very briefly summarize at the outset these conclusions. First of all, as a matter of positive law I believe that the express language of the MPN is most 
reasonably read as not creating contractual rights for Direct Loan borrowers to later avail themselves of the current PSLF program debt forgiveness privileges, $\underline{\text { nor }}$ as creating a contractual right that any debt so forgiven receive the current favorable tax treatment. That being said, however, the argument that those borrowers have such contractual rights on the basis of the implied covenant of good faith and fair dealing is very plausible, at least for those few borrowers who can demonstrate that they had a reasonable expectation at the time they took out their loan that they would have such rights. In addition, the related but distinct argument that the government should be contractually bound by promissory estoppel principles to honor those debt forgiveness and tax treatment rights also has some force, again at least with regard to those few borrowers who can demonstrate that they actually relied upon later having those rights at the time when they entered into their loan agreements, or when they later accepted public service employment, although there are some strong counter-arguments against the application of promissory estoppel principles here to create such contractual rights. Finally, a robust unconscionability challenge can be mounted against enforcement of those MPN terms that make this debt forgiveness and favorable tax treatment only a privilege rather than a contractual right by subjecting those privileges to retroactive alteration by later-adopted statutes, at least with regard to those high- 
debt borrowers who were unaware of or who did not understand this conditional language, and who would be severely impacted by the loss or substantial curtailment of their debt forgiveness rights or their favorable tax treatment.

If it is determined that Direct Loan borrower do not have these two contractual rights than my conclusion is that the government would be permitted to retroactively abolish the PSLF program, mooting the issue of the permissibility of retroactively abolishing the tax exemption. ${ }^{43}$ If one assumes for the sake of argument, however, that borrower contractual rights to current PSLF program debt forgiveness and the current tax treatment of forgiven debt can be justified by one or more of the above legal theories, that then raises the difficult question as to whether the federal government has the power to retroactively abrogate one or both of those contractual rights by statute without providing compensation to those borrowers adversely impacted. I have concluded that these contractual rights, if they exist, should be regarded as "property" that is protected by the Takings Clause of the Constitution against statutory curtailment or elimination without payment of compensation.

As a matter of policy, while I recognize that there is a sharp tension between 
the expectations of many current Direct Loan borrowers employed in public service that they will eventually be able to obtain debt forgiveness with favorable tax treatment under the PSLF program, and the legitimate public concerns that have been expressed regarding the excessive costs and regressive incidence of the debt forgiveness benefits of the program, I do not have strong feelings or any special insights as to how this tension should be resolved. I would suggest for discussion one compromise resolution; continuing the program's debt forgiveness benefits but adopting a statute which retroactively treats debt forgiven under the PSLF program as taxable income, as is now done for the other federal incomebased loan repayment programs. There are of course other resolutions possible that might better balance these interests. The sooner that these questions are resolved, the better for all concerned. 


\section{THE DIRECT LOAN MASTER PROMISSORY NOTE}

The following six provisions of the current MPN document for Direct Loans each explicitly or implicitly refer to the PSLF program and are therefore relevant for the subsequent analysis of whether vested contractual rights to debt forgiveness and tax exemption under the current terms of the PSLF program and the IRS Code are created by execution by the borrower of that MPN. ${ }^{44}$

1) On page 2 of the MPN:

\section{“GOVERNING LAW}

The terms of this Master Promissory Note (MPN) will be interpreted in accordance with the Higher Education Act of 1965, as amended (the HEA) (20 U.S.C. 1070 et seq.), the U.S. Department of Education's (ED's) regulations, any amendments to the HEA and the regulations in accordance with the effective date of those amendments, and other applicable federal laws and regulations. Throughout this MPN, we refer to these laws and regulations collectively as the "Act."'

2) On page 2 of the MPN:

\section{"REPAYMENT}

You must repay the full amount of the loans made under this MPN, plus accrued interest."

3) On page 3 of the MPN:

"William D. Ford Federal Direct Loan Program Direct Subsidized Loan and Direct Unsubsidized Loan Borrower's Rights and Responsibilities Statement

\section{IMPORTANT NOTICE}


This Borrower's Rights and Responsibilities Statement provides additional information about the terms and conditions of the loans you receive under the accompanying Master Promissory Note (MPN) for Direct Subsidized Loans and Direct Unsubsidized Loans."

4) On page 4 of the MPN:

\section{"LAWS THAT APPLY TO THIS MPN}

The terms and conditions of loans made under this MPN are determined by the HEA and other applicable federal laws and regulations. These laws and regulations are referred to as "the Act" throughout this Borrower's Rights and Responsibilities Statement.

NOTE: Any amendment to the Act that affects the terms of this MPN will be applied to your loans in accordance with the effective date of the amendment."

5) On page 8 of the MPN:

“DISCHARGE (HAVING YOUR LOAN FORGIVEN)

\section{Public Service Loan Forgiveness}

A Public Service Loan Forgiveness (PSLF) program is also available. Under this program, we will forgive the remaining balance due on your eligible Direct Loan Program loans after you have made 120 payments on those loans (after October 1, 2007) under certain repayment plans while you are employed full-time in certain public service jobs. The required 120 payments do not have to be consecutive. Qualifying repayment plans include the REPAYE Plan, the PAYE Plan, the IBR Plan, the ICR Plan, and the Standard Repayment Plan with a 10-year repayment period."

6) On page 9 of the MPN:

\section{"PROMISE TO PAY}


By signing this MPN, you ... agree to repay in full all loans made under this MPN according to the terms and conditions of the MPN."

The MPN makes no reference to Section 108 of the IRS Code, which provides an exemption from inclusion in taxable income for student loan debt that is forgiven under the PSLF program from being taxed as ordinary income. ${ }^{45}$ 


\section{THE AMOUNT OF DEBT LIKELY TO BE FORGIVEN UNDER THE}

\section{PSLF PROGRAM}

There is unfortunately not adequate data available at this time to offer with confidence precise estimates as to how many people will take advantage of the generous PSLF debt forgiveness provisions each year once people begin qualifying for debt forgiveness in October of 2017 after making regular repayments of Direct Loans while having been employed by a qualifying public service organization for at least 10 years.

Before the PSLF program was first established in 2007 the Congressional Budget office estimated that if the proposed PSLF legislation was adopted "about 50,000 new borrowers each year would eventually be eligible for, and participate in, income-contingent loan forgiveness each year" under this program. ${ }^{46}$ However, this early pre-enactment estimate was little more than a guess as to the eventual extent of participation in the program. In hindsight, this number will likely prove to be a significant underestimate of the extent of participation in this program, given that over a half-million borrowers have obtained annual employment certifications as of the end of $2016,{ }^{47}$ with 218,223 new borrowers doing so in 2016 alone ${ }^{48}$ even though such applications are not required, ${ }^{49}$ and given that it has 
been estimated that as many as one-quarter of the jobs in the economy qualify as public service jobs under the program's broad definition. ${ }^{50}$

There is also not adequate data available to precisely estimate the average amount and the range in size of the debts that will be forgiven each year under the PSLF program. The Congressional Budget Office annual participation estimate noted above did not include any estimates as to the aggregate amount of debt that would be forgiven each year. Many PSLF program participants will be persons with only relatively modest undergraduate debts and no graduate school debt, ${ }^{51}$ and will consequently likely have only relatively small amounts of debt remaining at the time of their debt forgiveness. However, it has been estimated that because of the substantial participation by high-debt graduate school borrowers who will benefit significantly from the program the median debt load of program participants could be over $\$ 60,000$, and that upwards of $30 \%$ of program participants could have debt loads over $\$ 100,000 .^{52}$ In addition, 2014 data revealed that at that time $80 \%$ of those Direct Loan borrowers who had received an annual PSLF employment certification had loan debts of over $\$ 30,000$, as compared to only $36 \%$ of all Direct Loan borrowers. ${ }^{53}$ 
Many law school and medical school graduates leave school with large sixfigure student debt loads, ${ }^{54}$ and if these lawyers and doctors take public service jobs paying relatively modest salaries they often will experience significant negative amortization of these debts over the following decade. Their monthly loan repayments that they will make under either the PAYE plan or the post-2014 version of the Income-Based Repayment repayment plan, one of which is usually selected by persons in this position, will be based in size upon their modest salaries and will normally not be sufficient to cover even the interest owing on those large loan debts, leading to negative amortization and rapid growth of their unpaid debt. Many of these persons will consequently have accumulated debt of upwards of $\$ 200,000$ or more ${ }^{55}$ that will be forgiven after 10 years of qualifying employment. Given these many large individual loan debts that will be forgiven the total amount of debt that is discharged could easily impose a substantial annual cost upon the U.S. Treasury amounting to billions of dollars. ${ }^{56}$

But precisely how many billions of dollars per year in costs to taxpayers is unclear. What is known for certain is that at least 24.9 million and perhaps as many as 31.9 million borrowers have taken out Direct Loans since October 1, 2007 that incorporate the current MPN provisions set forth above that relate in some 
fashion to the PSLF program, ${ }^{57}$ and that over half a million of these borrowers have filed at least one of the voluntary PSLF program employment certification forms with the $\mathrm{DOE},{ }^{58}$ and that roughly one-quarter of all jobs will qualify as public service jobs. ${ }^{59}$ But since there is no requirement that people register in some fashion for the PSLF program prior to eventually filing for debt forgiveness when they become eligible to do so there is no solid basis for forecasting how many borrowers will eventually apply, nor how large the aggregate amount of debt forgiven will likely be. But given how attractive the debt forgiveness terms of the PSLF program are, particularly for high-debt graduate school borrowers, and given how broadly public service employment is defined for PSLF program purposes, and given the fairly large and rapidly increasing number of annual employment certification forms that have been filed to date, the amount of debt forgiven each year under this program will eventually become quite substantial, ${ }^{60}$ likely large enough to lead to political efforts to impose limitations upon or even curtailment of the PSLF program. ${ }^{61}$

In order to make these impending financial consequences for taxpayers of the PSLF program more clear let me engage in an illustrative but hopefully realistic hypothetical calculation. Let me start by setting out some important 
baseline data. In 2015 a total of 143,276 new borrowers first received annual employment certifications from the DOE, ${ }^{62}$ and in 2016 a total of 218,223 new borrowers first received annual employment certifications. ${ }^{63}$ In 2014 the number of Direct Loan borrowers increased by 2.3 million, ${ }^{64}$ in 2015 the number of Direct Loan borrowers increased by 2.0 million, ${ }^{65}$ and in 2016 the number of Direct Loan increased by 1.6 million. ${ }^{66}$ These figures together suggest that upwards of a couple of hundred thousand people each year may enter the PSLF program loan forgiveness 10-year "pipeline." ${ }^{\prime 67}$ Another important statistic to consider is that approximately 1.89 million Direct Loan borrowers both currently work in public service positions and have enrolled in an income-based loan repayment plan, and will consequently likely have unpaid loan debt after 10 years of public service. ${ }^{68}$ In the long-term steady-state one would expect about $10 \%$ of these 1.89 million persons each year to meet the 10-year PSLF employment requirement, approximately 189,000 people each year, with approximately that many newly hired public service employees also entering the 10-year "pipeline" towards eventual debt forgiveness eligibility.

On the basis of this data regarding the number of new Direct Loan borrowers each year, the revealed extent of PSLF program interest through filings for annual 
employment certification, and the number of Direct Loan borrowers who both are public service employees and are enrolled in income-based loan repayment programs, I will (rather conservatively, I believe) project for the sake of this illustration that the eventual "steady-state" number of persons who will annually seek debt forgiveness under the PSLF program will be approximately $200,000 .{ }^{69}$

How much debt will be forgiven in total if this many people obtain forgiveness each year? The median amount of Direct Loan debt for persons who will later seek debt forgiveness under the PSLF program has been estimated at slightly over $\$ 60,000 .^{70}$ I will assume for this simple illustration that the average amount of Direct Loan debt owed by these persons upon their enrollment in one or another of the loan repayment plans is equal to this median debt estimate. ${ }^{71}$ Given that most of those persons will have spent the next 10 years after leaving school enrolled in either the PAYE plan or the post-2014 version of the Income-Based Repayment plan. under either of which they will only have had to make loan repayments equal to $10 \%$ of their disposable income, ${ }^{72}$ and given that the annual income for most persons working in qualifying public service jobs will be relatively modest, those loan repayments will on average barely be large enough to cover the annual loan interest charges, ${ }^{73}$ leaving on average the entire debt 
principle unpaid at the time debt forgiveness is sought. Now with an assumed 200,000 people a year having an average of $\$ 60,000$ each of loan debt forgiven, ${ }^{74}$ without tax consequences, that comes to $\$ 12$ billion/year of forgiven loan debt, ${ }^{75}$ obviously a very substantial cost to the Treasury.

This estimate of the annual steady-state PSLF program costs to the Treasury, strikingly large as it is, may well be too conservative. With approximately two million new Direct Loan borrowers each year, ${ }^{76}$ and with one-quarter of all jobs qualifying for the program, and with rapidly increasing rates of enrollment by Direct Loan borrowers in income-based loan repayment plans in recent years, the long-run steady-state rate of participation in this program, once it begins to widely bestow its generous benefits and these benefits become more broadly publicized and appreciated, could significantly exceed 200,000 persons/year, leading to even higher costs for taxpayers. If, for example, $15 \%$ of each year's approximately two million Direct Loan borrowers later utilize the PSLF program (still significantly less than the approximately $25 \%$ of jobs which qualify as public service jobs), ${ }^{77}$ that would lead to approximately 300,000 persons/year seeking debt forgiveness, ${ }^{78}$ at a total annual cost of approximately $\$ 18$ billion. $^{79}$ 
I am certain that annual costs in the neighborhood of \$12-18 billion will lead to political efforts to statutorily curtail or eliminate the PSLF program, probably calling for changes that will retroactively impact existing Direct Loan borrowers as well as prospective future borrowers if this can be legally justified. These efforts will be bolstered by those persons who are concerned by the highly skewed and regressive nature of the program's benefits in favor of high-debt law school and medical school graduates that I have noted. Let me now turn to consider the question of the legality of the retroactive application of such statutes to existing Direct Loan borrowers were they to be adopted. 


\section{BORROWER CONTRACTUAL RIGHTS TO INVOKE DEBT}

\section{FORGIVENESS AND TAX EXEMPTION OF FORGIVEN DEBT}

The United States government is subject to the same obligation to perform its contractual obligations as are private parties, ${ }^{80}$ except in those few instances where special sovereign immunity defenses apply, which do not include ordinary student loan transactions. ${ }^{81}$ The issue here is therefore whether the MPN documentation that is now used for Direct Loan transactions contractually obligates the government to provide borrowers with those PSLF program debt forgiveness provisions and the related tax laws that existed when the contracts were entered into, and if so whether these borrower contractual rights are subject to abrogation by later-enacted changes in those laws.

Let me consider separately in this Part IV each of four different rationales that can be offered in support of the argument that Direct Loan borrowers who took out their loans after October 1, 2007 and prior to the effective date of any legislative changes affecting the PSLF program or related tax laws have a contractual right both to invoke the program's debt forgiveness terms and avail themselves of the debt forgiveness-related tax laws that were in force at the time that they took out their loans. These four rationales are: 1) an argument based 
upon the express terms of the MPN, 2) an argument based upon the implied covenant of good faith and fair dealing, 3) a promissory estoppel argument based upon forseeable borrower reliance on being able to later invoke the PSLF program debt forgiveness terms and the related tax laws that were in force at the time they took out their loans, an 4) an argument based upon the unconscionability of those MPN terms that might retroactively subject borrowers to later-enacted legislative changes in the program. I will later in Part V start with the assumption that these contractual rights can be established under one or more of these theories, and I will then turn to consider whether the federal government could legally adopt statutes abrogating one or both of these rights without being subject to Constitutional limitations that would either bar such actions or require it to provide compensation to those borrowers.

A. The Express Contractual Terms Argument.

The MPN on page 8 as noted above clearly states the terms of the debt forgiveness rights that borrowers currently have under the PSLF program. However, the MPN also appears to incorporate by reference later-enacted laws that could retroactively curtail or even eliminate those borrower rights. For example, on page 2 the MPN states that "the terms of this Master Promissory Note (MPN) 
will be interpreted in accordance with ....any amendments to the HEA [in which the PSLF program authorization is embedded] and the regulations in accordance with the effective date of those amendments, and any other applicable federal laws and regulations." On page 4 the MPN then similarly states in bold font that "any amendment to the Act [the HEA] that affects the terms of this MPN will be applied to your loans in accordance with the effective date of the amendment."

One could argue that this MPN language should be interpreted as only justifying the incorporation of the terms of statutory amendments into new Direct Loans that are taken out by borrowers after the effective date of those amendments, and not into prior loans. However, this argument will face considerable difficulties. The several references in the statutory incorporation language of the MPN noted above to "this MPN" $" 82$ strongly suggests that later statutory amendments to the Higher Education Act or its implementing regulations will also apply to modify earlier Direct Loans as of the date of statutory enactment, even if those statutes may have retroactive impacts on the rights and duties created under those earlier loan agreements, although these references are not quite as clear in this regard with respect to amendments to federal laws and regulations other than the Higher Education Act, such as the tax laws. My conclusion here is that if one 
considers only the express terms of the MPN, and not any duties of good faith and fair dealing that would be implied into the loan contracts to supplement those express terms, nor any additional lender contractual duties that may be based upon forseeable borrow reliance on the loan terms, nor any possible unconscionabilitybased reformation of the loan terms (which arguments are each discussed more fully below), those MPN terms appear to not preclude retroactive application of statutory amendments that would limit or even eliminate current PSLF program debt forgiveness privileges or the current tax exemption of forgiven debt for Direct Loan borrowers who took out those loans prior to the effective date of those amendments.

In other words, under the express terms of the MPN these Direct Loan borrowers would not have contractual rights that could not be unilaterally modified or rescinded by the government by statute. Let me here note here that there is a reasonable case to be made that the express terms of the MPN are not clear enough to permit the retroactive imposition of statutory limitations of PSLF program debt forgiveness rights or less favorable tax treatment of forgiven debt. That argument has some plausibility and appeal, given the vagueness and generality of the references to possible later-enacted statutes that are contained in the MPN. But in 
my opinion it is not likely to prevail.

The DOE in its 2008 regulations implementing the PSLF program rather summarily took the position that the express terms of the MPN do not provide Direct Loan borrowers with a contractual right to invoke the program's debt forgiveness terms. ${ }^{83}$ A later short 2016 study by the AccessLex Institute reached the same conclusion. ${ }^{84}$ However, there are at least three other promising contract law avenues to explore, one or more of which may suffice to establish contractual borrower rights to debt forgiveness and favorable tax treatment thereof, at least for a subset of Direct Loan borrowers if not all of them. None of these alternative theories of contractual obligation appear to have been considered by either the DOE or the AccessLex Institute. Let me turn to these alternative theories.

B. The Implied Covenant of Good Faith and Fair Dealing Argument. While as discussed above the express terms of the current MPN should and would probably be interpreted to not impose any contractual obligation on the part of the federal government to existing Direct Loan borrowers to continue to provide them with the current PSLF program debt forgiveness benefits or their favorable tax treatment if that program and/or the tax laws were legislatively amended to 
curtail these benefits, there is case law holding the government liable for breach of contract even absent violation of any express contractual terms on the basis of the imposition of an implied covenant of good faith and fair dealing. ${ }^{85}$ In Centex v.

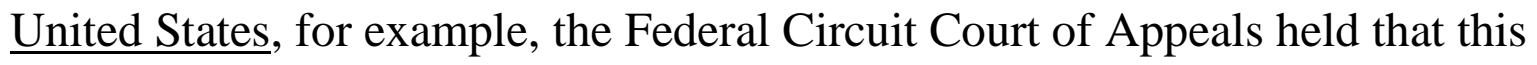
covenant was implied into governmental contracts with a private party, and that the covenant imposed a duty upon the government "not to act so as to destroy the reasonable expectations of the other party as to the fruits of the contract." ${ }^{\text {}}$

This implied covenant of good faith and fair dealing therefore imposes some limits on the ability of the government to retroactively alter the terms of Direct Loan agreements by statute. For example, consider the extreme situation of the passage of a statute that unilaterally increased the fixed interest rate on previously executed Direct Loans by a significant amount above the rate that the borrowers had agreed to. While such a statute would technically conform to the express MPN terms that arguably allow without restriction statutory changes with retroactive impacts on loan terms, such an attempt by the government to unilaterally impose a much higher interest rate on prior borrowers than what was originally agreed to would surely be regarded by the courts as contrary to the reasonable expectations of typical borrowers that their interest payment obligations under a nominally fixed 
interest rate loan agreement would remain unchanged for the term of the loan. It would therefore be in violation of the implied covenant of good faith and fair dealing. Another way to state this conclusion would be to say that the borrowers have an implied contractual right to be charged no more than the originally agreed interest rate.

In a similar fashion, for those many borrowers who have large student loans and who later take relatively low-paying qualifying public service jobs, ${ }^{87}$ such as many law school and medical school graduates, either the termination of the PSLF program debt forgiveness privileges or the elimination of the tax exemption for forgiven debt under this program would have severe adverse financial consequences that would be economically equivalent to a rather large unilateral increase in their fixed interest payment obligations. ${ }^{88}$ Such statutes should arguably be judicially regarded in a similar manner as being a violation of the borrowers' contractual rights created by that implied covenant.

Despite the express MPN language that is arguably sufficient to allow retroactive incorporation of later legislative enactments that curtail debt forgiveness rights or tax law rights into the Direct Loan agreements, the reality 
here is that the typical student loan borrower does not (and probably could not) give the fine print of the extensive and detailed MPN loan documentation such a close, lawyerly reading that would reveal such risks. The typical Direct Loan borrower is young and financially relatively inexperienced, and gives that detailed loan documentation only a cursory reading at best before signing it. Those typical borrowers would generally expect (and would arguably be reasonable in doing so) that not only would their initial fixed interest payment obligations remain unchanged, but that they would also to be able to later avail themselves of the PSLF program's debt forgiveness terms and the relevant tax law provisions that existed at the time of their loan, given that the substantial curtailment or elimination of those debt forgiveness terms or tax benefits would be just as devastating to them as would be a large unilateral interest rate increase. They might understand that later-enacted statutes could impact their subsequent disclosure or other technical regulatory compliance obligations in some fashion, perhaps significantly increasing their burdens in these regards, but they would probably not anticipate that statutory changes might be retroactively imposed on their loan agreements that would radically and adversely alter its basic financial parameters. 
Now one should recognize that it is possible that a court that was trying to determine whether Direct Loan borrowers had contractual rights to debt forgiveness and the current tax benefits for forgiven debt under this implied covenant, in the face of an attempted statutory curtailment of those privileges, might elect to apply the "reasonable expectations" criterion under this implied covenant to the particular litigants before it in a fact-specific manner rather than in an more conventional "objective" manner based on hypothetical average contracting party characteristics, even though the latter approach is quite commonly used in many contexts for legal assessment of the "reasonableness" of particular conduct. Rather than postulating a hypothetical Direct Loan borrower of average awareness of and expectations regarding the fine-print loan terms whose reasonable expectations were to be protected, and then determining whether that hypothetical person had a reasonable expectation of debt forgiveness and favorable tax treatment that merited protection through declaration of contractual rights, the court may require the litigant before it to provide sufficient evidence that he or she did in fact have reasonable expectations of having a contractual right to debt forgiveness, and of a right to the current favorable tax treatment thereof.

Under this judicial approach any litigants who would be asserting that they 
had both of these contractual rights under the MPN's implied covenant of good faith and fair dealing would have the considerable burden of having to provide sufficient evidence to establish a favorable position on each of six legal issues: 1) whether they were aware of the PSLF program debt forgiveness terms set forth in the MPN when they executed their loan documents, 2) if so, whether they expected that their rights to utilize those debt forgiveness terms would survive a later legislative amendment that would attempt to curtail those rights, and if so, 3) whether, given their particular degree of legal sophistication, such expectations were reasonable, 4) whether they were aware of the favorable tax treatment that debt forgiven under the PSLF program was accorded when the executed their loan documents, 5) if so, whether they expected that their rights to invoke those tax benefits would survive a later legislative amendment that would attempt to curtail those rights, and if so, 6) whether, given their particular degree of legal sophistication, such expectations of contractual tax benefits immune to statutory abridgement were reasonable.

Under such a fact-specific "reasonable expectations" inquiry only those persons who could satisfy the first three issues noted above by providing sufficient evidence that they were aware of the current PSLF program debt forgiveness 
benefits, and that they reasonably expected those benefits to be contractual rights that they held, would be accorded a contractual right to those benefits. In similar fashion, only those persons who could satisfy the second three issues noted above by providing sufficient evidence that they were aware of the current favorable tax treatment of debt forgiven under the PSLF programs, and that they reasonably expected those tax terms to be contractual rights that they held, would be accorded a contractual right to that tax treatment.

A judicial requirement that such fact-specific showings be made would be devastating to the implied covenant argument for establishing contractual rights. These fact-specific showings with regard to each of perhaps numerous loan transactions taking place as long as 10 years earlier could be made by at most only a very small proportion of Direct Loan borrowers. This requirement would as a practical matter be tantamount to rejecting the argument that these two contractual rights exist on the basis of the implied covenant of good faith and fair dealing.

However, given the clear advantages of judicial economy of reaching a single blanket ruling on this question of the existence of implied covenant-based contractual rights that would apply equally to all Direct Loan borrowers, and that 
would avoid the need for a great deal of fact-specific litigation, a court may well be willing to make this "reasonable expectations" determination on "objective" criteria; i.e., on the basis of the presumed knowledge and expectations of a hypothetical "average" Direct Loan borrower. If so, that court may well conclude that this hypothetical borrower had awareness of and expectations regarding being able to invoke the PSLF program's debt forgiveness terms, and that these expectations were reasonable and therefore create contractual rights under the implied covenant of good faith and fair dealing.

This "objective reasonable expectations" argument would be less powerful with regard to establishing a contractual right that would preclude the retroactive application of a change in the IRS Code that would limit or eliminate the favorable tax treatment of forgiven debt under the PSLF program. The MPN which refers explicitly to the PSLF program's debt forgiveness benefits, but makes no explicit reference to the favorable tax treatment of that forgiven debt that would make borrowers aware of those tax benefits, or that would encourage borrower expectations that those tax benefits would remain available years later at the time of debt forgiveness. In addition, given the general broad judicial acceptance (and reasonably wide public recognition) of the view that amendments to the IRS Code 
that have adverse retroactive effects upon particular taxpayers are nevertheless permitted, ${ }^{89}$ an argument can be made that any such expectations that the relevant tax laws will remain unchanged are unreasonable.

\section{The Promissory Estoppel Argument.}

The essence of the implied covenant of good faith and fair dealing "reasonable expectations" argument set forth above can presented in a related but slightly different guise if this implied covenant is determined to not be broad enough in this context to provide contractual debt forgiveness rights and the right to the current tax treatment of such forgiven debts, at least for those Direct Loan borrowers who cannot make the required fact-specific showings, if not all borrowers. Another legal doctrine which may provide some contractual protection for these borrower expectations is the broadly accepted doctrine of promissory estoppel..$^{90}$

Under the promissory estoppel principle, if the government should "reasonably expect" that a Direct Loan borrower would rely upon a promise as to the later availability of the current PSLF program debt forgiveness terms and their tax treatment, and the borrower then does so rely in taking out the loan, or in later 
accepting public service employment, then the government will have to recognize that the borrower has a contractual right to invoke those terms "to the extent justice requires." $" 91$ The focus of the inquiry here would be whether the government should reasonably expect borrower reliance upon the later availability of those terms, rather than upon the reasonableness of those borrowers' expectations in relying upon those terms which would be the focus of the implied covenant of good faith and fair dealing inquiry discussed above. If it is determined that the government should reasonably expect borrower reliance (whether or not the borrowers have behaved reasonably in so relying), then the final issue presented would then be whether the demands of justice would then call for contractual enforcement of those debt forgiveness and tax treatment terms, in whole or in part. The reasonableness of the borrower's reliance could, however, be a relevant factor in this final determination as to what resolution of the question best furthers justice.

The principles of promissory estoppel apply to impose contractual obligations upon the federal government in the same manner as they apply to private parties. ${ }^{92}$ There is a distinction drawn in the law when a party seeks to utilize the earlier and related doctrine of equitable estoppel to bind the government to fraudulent or mistaken representations of its agents. The courts under such 
circumstances will not hold the government liable for those representations unless the agent was acting within the scope of their authority. ${ }^{93}$ However, when a promissory estoppel claim is made based upon the authorized promissory representations of a government agent, the same rules are applied as are to private parties under such circumstances.

This promissory estoppel argument for holding the government contractually obligated to allow borrowers PSLF program debt forgiveness and the favorable tax treatment of forgiven debt is interesting, but there are several plausible counterarguments that can be made against this basis for establishing these contractual rights. One straightforward counter-argument would be that the express terms of the MPN simply do not promise that the PSLF program's debt forgiveness terms will remain available indefinitely for borrower invocation, nor do they include any specific reference to restrictions on changes in the tax treatment of forgiven debt. Those MPN terms instead make it reasonably clear to a legally sophisticated reader that later legislative enactments may retroactively limit or even eliminate these debt forgiveness and tax treatment privileges. If no promises at all were made to borrowers this would sharply undercut the promissory estoppel rationale for imposing contractual obligations upon the government. 
A second, related counter-argument would be that any promises that may have been made in the MPN as to the future availability of current PSLF program debt forgiveness terms or favorable tax treatment have been expressly made subject to later legislative enactments. Now it may be reasonable for the government to expect typical student loan borrowers without legal training to overlook the hedged nature of these conditional promises, assuming that they are promises at all, and to rely upon them as though they were unconditional commitments. However, borrower reliance on the mere hope that the PSLF program debt forgiveness terms and the tax laws applicable to forgiven debt will remain unchanged, despite the MPN's express references to possible later limiting enactments, is therefore unreasonable. Achieving justice arguably does not require the courts to order the government to meet people's unreasonable contractual expectations.

Finally, the promissory estoppel argument raises the subsidiary question of whether to prevail with this argument a particular Direct Loan borrower should have to show by substantial evidence that they actually relied upon having the opportunity to later avail themselves of the PSLF debt forgiveness terms and their 
favorable tax treatment at the time when they entered into their loan agreements, or when they later took a public service position, or whether such reliance will be presumed as a matter of law on the basis of "objective" criteria; i.e., an analysis of whether a hypothetical "average" Direct Loan borrower would have so relied. If a borrower must demonstrate actual reliance on these presumed MPN promises to be able invoke a promissory estoppel-based contractual right to debt forgiveness and favorable tax treatment thereof, this would obviously bar most if not virtually all borrowers from a favorable finding, in a fashion similar to what I have shown regarding what a fact-specific showing requirement would do to hinder the implied covenant theory of contractual obligation.

D. The Unconscionability Argument.

Finally, even if the MPN terms are interpreted to permit the government to subject borrowers to later-enacted legislation that would significantly alter their PSLF program debt forgiveness and favorable tax law treatment privileges, even after considering the implied covenant and promissory estoppel theories of contractual obligation discussed above, a final argument can be made that such alterations should not be allowed because they are so unfair and surprising to borrowers as to be unconscionable. ${ }^{94}$ This unconscionability argument would be 
based upon the claim that the express MPN provisions that allow for retroactive legislative alterations of loan terms and tax treatment present both significant procedural and substantive unfairness, satisfying the usual judicial requirements that both forms of unfairness be present to some significant extent to justify judicial abrogation of those provisions on unconscionability grounds. ${ }^{95}$ If a court accepted this argument it could then reform the loan agreements by refusing to enforce those particular MPN provisions that allow for subsequent unilateral government amendment by statute, thus giving borrowers in effect a contractual right to PSLF program debt forgiveness and the favorable tax treatment thereof.

The procedural unfairness argument that could be made here would be that the terse and legalistic MPN provisions relating to the possibility of alteration of the loan terms by subsequent legislation do not clearly reveal to typical Direct Loan borrowers, who in general have not had any formal legal training, the dramatic nature of the increased burden that could later be legislatively imposed on them by the elimination of their debt forgiveness and favorable tax treatment rights. This argument would once again present the related sub-issue as to whether a fact-specific showing here will be required by courts. Will those borrowers who cannot demonstrate that they were unaware of the possibility of such retroactive 
legislation at the time they took out their loans be regarded differently and less favorably than those less sophisticated borrowers who can somehow demonstrate that they were not consciously aware of this risk?

A class action challenge to a later-enacted statute that curtailed debt forgiveness rights that was mounted based on this contractual theory of reformation due to unconscionability grounds may be required by the court to bifurcate the plaintiff class with regard to this particular issue. Once again, if courts required that borrowers be able to provide sufficient evidence to demonstrate that they were unaware at the time of contract formation of the existence and significance of the MPN terms that make borrower privileges conditional with regard to later statutory amendments, this would be quite burdensome and would likely defeat most if not virtually all borrower claims. However, once again considerations of judicial economy might cause courts to instead apply their determination of the extent of knowledge and understanding of a hypothetical "average" Direct Loan borrower for all such unconscionability claims.

The substantive unfairness argument would focus on the major financial 
implications of the loss of those debt forgiveness and tax treatment privileges for borrowers, as compared to the size of the loan obligations they have originally undertaken. This argument may also present a related sub-issue: Should those high-debt borrowers, such as law school and medical school graduates, who will suffer greatly from the loss of debt forgiveness privileges be treated differently from those many borrowers who have more modest loan balances, and who therefore will not be as strongly impacted? This difference in the significance of losing these privileges between these borrower groups may also call for partition of an unconscionability class action into two (or more) different lawsuits on this particular issue. 


\section{FEDERAL GOVERNMENT POWER TO RETROACTIVELY LIMIT}

PSLF DEBT FORGIVENESS AND TAX TREATMENT PRIVILEGES

If it is determined that current Direct Loan borrowers do not have contractual rights to later avail themselves of the PSLF program debt forgiveness privilege or current tax law treatment there do not appear to be any Constitutional limitations that would be sufficient to bar enforcement of a federal statute that would retroactively terminate that privilege. However, if the program's debt forgiveness terms were left in force but the tax exemption now given to that forgiven debt was statutorily eliminated, there is some question as to whether such legislation would pass Constitutional due process scrutiny, although I believe that it would.

The courts have long permitted tax legislation that has retroactive impacts on some taxpayers. ${ }^{96}$ As early as 1880 it was established that taxation for a public purpose is not a taking of private property in violation of the Takings Clause of the Constitution. $^{97}$ In addition, a taxpayer's mere reliance upon an existing tax provision remaining in force is insufficient to establish that a tax law change is a Constitutional violation. ${ }^{98}$ However, upon occasion a tax law change with retroactive impact has been challenged as a violation of the substantive due process 
requirements of the Constitution on the basis that the length of the period of retroactivity reaching back from the date of statutory enactment is excessive.

Now most tax legislation is made retroactive only to the beginning of the year of enactment, and such legislation has been routinely upheld against such substantive due process challenges. ${ }^{99}$ However, tax laws that reach back further than one year to impose changes in the tax treatment of prior events are on rare occasions successfully challenged on substantive due process grounds. For example, in Nichols v. Coolidge the Supreme Court disallowed the retroactive application of an estate tax provision that changed the tax treatment of a property transfer that had taken place 12 years earlier. ${ }^{100}$ In a later case the Supreme Court endorsed this ruling and contrasted it with the different result reached in many other instances where the "retroactive effect is limited." 101

A change in the tax laws governing debt forgiven under the PSLF program would potentially have retroactive effects for some borrowers going as far back as 1994 when the Direct Loan program first went into effect, ${ }^{102}$ thus far exceeding the 12 years of retroactive application found to be unacceptable in Nichols $\mathrm{v}$. Coolidge. This potentially long period of retroactivity exists because while a 
borrower must have worked for 10 years in qualifying public service after October 1, 2007 to obtain debt forgiveness, if the borrower meets that requirement he will be able to have any remaining balance on any Direct Loans forgiven, even if some or all of those loans were taken out prior to October 1, 2007. Now as a practical matter the large majority of Direct Loans that will be forgiven under the PSLF program, starting in October of 2017, will be post-2007 loans that the borrower will have taken out within 10 years or less of the time of seeking debt forgiveness. However, there will likely also be some Direct Loans that were taken out more than 10 years before PSLF program debt forgiveness is sought, and that were then partially repaid under extended 20- or 25-year income-based loan repayment plans and will not have been fully repaid by the time PSLF program debt forgiveness is sought. So a tax law change here could conceivably have retroactive impact for a particular taxpayer extending back before 2007 and perhaps all the way back to 1994 !

However, it was not until the PSLF program was adopted in 2007 that a Direct Loan borrower could have formed an expectation of PSLF program debt forgiveness and the tax exemption of this forgiven debt, so perhaps it would be more appropriate to regard the period of retroactive impact of a tax law change as 
extending back only to October 1, 2007 when those expectations of debt forgiveness and favorable tax treatment could have first arisen, even if some of the loan debts that would later be forgiven were incurred well prior to that date. Still, even if framed in this manner such a statute would be imposing a retroactive period of up to at least 10 years in length - longer for some borrowers if the hypothetical new tax law is adopted after 2017 -- and therefore would perhaps be open to challenge on substantive due process grounds under the rationale of Nichols $\mathrm{v}$. Coolidge which as noted invalidated a tax law that had a retroactive impact extending back 12 years. But I doubt that such an argument would prove successful, given the broad judicial support for retroactive tax laws, ${ }^{103}$ and given the very large revenue consequences of invalidating such a statute, which I have estimated earlier would recapture one-quarter to one-third of the $\$ 12$ billion to $\$ 18$ billion/year of forgiven debt. .

For the remainder of this Part V I will assume for the sake of argument that it has been determined that under one or more of the legal theories discussed above at least some Direct Loan borrowers do have a contractual right to utilize the current PSLF program debt forgiveness rights, and a contractual right to the current favorable tax treatment of any debt forgiven. Does the contractual status of those 
borrowers' rights affect the federal government's ability to retroactively terminate one or both of those rights under the Constitution without providing compensation to the adversely affected borrowers? My conclusion here is that these contractual rights would each be regarded as "private property" and protected against retroactive statutory elimination by the Takings Clause of the Constitution. ${ }^{104}$

Let me explain my reasoning. The U.S. Constitution's Contracts Clause prohibits any state government from adopting a law that would impair its contractual obligations, ${ }^{105}$ but it has long been recognized that this provision applies only to the states and not to the federal government. ${ }^{106}$ Any Constitutional challenge to federal statutes that impair the contractual rights of a private party in a contract with the federal government, such as the assumed contractual rights of Direct Loan borrowers to utilize PSLF program debt forgiveness terms and to have favorable tax treatment of the forgiven debt, would have to be based on the argument that the statutes violate the Takings Clause of the Constitution which prohibits the taking of private property without providing just compensation. ${ }^{107}$

Contract rights are generally deemed to constitute "private property" as that phrase is used in the Takings Clause, ${ }^{108}$ but there are important exceptions made to 
this general rule. For example, in Bowen v. $\underline{P O S S E}^{109}$ the U.S. Supreme Court stated in sweeping terms that contractual arrangements, including those to which a sovereign itself is party, remain subject to subsequent legislation, ${ }^{110}$ and held that the contractual right of the State of California to terminate its participation in the Social Security system did not constitute a property right within the meaning of the Fifth Amendment, ${ }^{111}$ but that such a right remained "subject to the sovereign's jurisdiction, and [that jurisdiction] will remain intact unless surrendered in unmistakable terms." 112 The Bowen court distinguished this lesser right from the hardier property rights that would be created by a contractual debt of the government, or by a government obligation to otherwise provide benefits under a contract. ${ }^{113}$

Under the reasoning of the Bowen case, if the Direct Loan borrowers are determined to have a contractual right to invoke PSLF program debt forgiveness, as I am assuming here, this right would appear to be of the nature of a governmental obligation to provide benefits, and where the government's right to unilaterally alter or terminate those benefits has been "surrendered in unmistakable terms." That right would therefore deserve the usual "private property right" Takings Clause Constitutional protection that would bar its termination by statute 
without the government providing compensation. In similar fashion, if these Direct Loan borrowers are determined to also have a contractual right to the currently favorable tax exemption for forgiven debt, under Bowen this right would also appear to be of the nature of a government obligation to provide benefits that merited such Constitutional Takings Clause protection. The retroactive taxation jurisprudence briefly discussed above that broadly allows the adoption of tax laws with retroactive impact (if the period of retroactivity is not excessively long) does not appear to be here applicable because those prior cases allowing for retroactive measures do not address the unusual circumstances assumed to be present where the government has specifically contracted to provide a certain tax treatment for a transaction. 


\section{CONCLUSION}

As I have discussed above, I believe that the express language of the MPN should be interpreted to allow the government to retroactively impose statutory limitation or even elimination of PSLF program debt forgiveness privileges for prior Direct Loan borrowers, ${ }^{114}$ and to retroactively change the tax laws applicable to any forgiven debt. Direct Loan borrowers do not appear to have an express contractual right to either debt forgiveness or favorable tax treatment of forgiven debt.

Under the implied covenant of good faith and fair dealing, however, a fairly strong case can be made that Direct Loan borrowers have an implied contractual right to debt forgiveness under the PSLF program and to the current favorable tax treatment of debt so forgiven, if not all borrowers then at least those few borrowers who can demonstrate that they reasonably expected to have such contractual rights when they entered into their loan agreements.

In addition, a related but distinct argument can be made that the government should be bound by promissory estoppel principles to contractual commitments to honor those debt forgiveness and tax treatment privileges originally articulated in 
the Direct Loan documentation, again if not for all borrowers then at least with regard to those few borrowers who can demonstrate that they actually relied upon later having those rights at the time when they entered into their loan agreements, or when they later took public service employment. However, as I have noted there are several strong counter-arguments that can be made against imposing contractual liability on the government here on a promissory estoppel theory.

Finally, a robust unconscionability challenge can be mounted against enforcement of the MPN terms that allow for retroactive elimination PSLF program debt forgiveness privileges for Direct Loan borrowers by later-enacted statutes, seeking reformation of those contracts to provide contractual protection to borrowers against such statutes, if not for all borrowers than certainly at least with regard to those high-debt borrowers who can demonstrate that they were both unaware of this possibility at the time of contracting and would be severely impacted by the loss or substantial curtailment of their debt forgiveness rights.

In summary, I think that it is an open question whether the courts would regard the PSLF program debt forgiveness terms as a contractual obligation of the government under the post-October 1, 2007 Direct Loan agreements, rather than as 
merely a revocable privilege, under one or more of the above contractual theories of liability if this matter were litigated in the context of retroactive statutory curtailment or elimination of those privileges. I have here considered several arguments that could be made in this regard, and while some of them have considerable merit at least for a small subset of Direct Loan borrowers the proper resolution of the question as a matter of positive law is unclear. For the reasons that I have discussed, however, I think that it is much less likely that the courts would regard the privilege of favorable tax treatment of debt forgiven under the PSLF program as a contractual obligation of the government.

If one assumes for the sake of argument that the existence of borrower contractual rights to both debt forgiveness and favorable tax treatment can be justified by one or more of the above theories, that raises the difficult question as to whether the federal government then still has the power under the Constitution to retroactively abrogate one or both of those contractual rights by statute. I have concluded that a strong case can be made that if borrowers have contractual rights to debt forgiveness these rights should be regarded as property rights that under the Takings Clause cannot be retroactively abrogated without the payment of compensation. I have also concluded that if borrowers have a contractual right to 
the current favorable tax treatment of forgiven debt this right should also be regarded as a property right that similarly under the Takings Clause cannot be retroactively abrogated without the payment of compensation.

The Obama Administration's 2016 proposal to limit PSLF program debt forgiveness eligibility was not adopted, and the recent Trump Administration proposal to prospectively abolish the PSLF program altogether for most Direct Loans taken out as of July $1,2018^{115}$ may or may not be adopted. But in any event, given the very large annual costs that the debt forgiveness provisions of this program are likely to impose upon the Treasury in later years once substantial numbers of people begin to obtain debt forgiveness, and given the highly skewed regressive distribution of the benefits of the program's debt forgiveness terms in favor of mid-career lawyers and doctors, there are likely to be later attempts made to statutorily curtail or eliminate this program, or to reduce or eliminate its favorable tax benefits, in a manner that will have retroactive impacts upon prior Direct Loan borrowers.

Finally, if such statutes with retroactive impacts are adopted there will surely be court challenges to those statutes asserted along the lines of the arguments that I 
have outlined above. Such challenges will present not only difficult legal issues but also hard policy questions as to how to best balance the widespread reliance by existing Direct Loan borrowers on being able to later avail themselves of the PSLF program debt forgiveness terms against the legitimate public concerns regarding the large costs and the somewhat regressive incidence of the program's benefits.

I do not have strong feelings or any special insights as to how this tension should be resolved. I do suggest for discussion one possible compromise approach. Congress could adopt a statute which continues unchanged the PSLF program's debt forgiveness eligibility and benefits, but which would treat debts forgiven under the PSLF program as taxable income as is now done for the other federal income-based loan repayment programs. Such a statute would immediately recapture approximately one-quarter to one-third of the debt forgiveness benefits in new income tax revenues, and would do so in a modestly progressive manner as it imposed larger taxes on higher-debt (and presumably also higher-earning) lawyers and doctors. This approach would, however, create a troubling "tax bomb" effect in that persons would now be burdened with what in some instances would be a very substantial income tax obligation without being provided with any funds to pay those taxes. ${ }^{116}$ For the typical undergraduate borrower with a $\$ 30,000$ initial 
loan debt that as I have discussed earlier would have approximately $\$ 25,000$ of debt forgiven, ${ }^{117}$ this would impose a tax liability of approximately $\$ 6,000$ to $\$ 8,000$, a significant but not a crushing financial obligation. For lawyers or doctors with upwards of $\$ 200,000$ of debt forgiven, ${ }^{118}$ however, their tax bill could be as high as $\$ 50,000$ to $\$ 70,000$ or more, which may well be beyond some persons' capacity to pay.

In my earlier analysis of the comparable tax bomb impacts for high-debt law school graduates of large forgiven debts of $\$ 200,000$ or more being treated as taxable income under the PAYE and Income-Based Repayment plans after either 20 or 25 years, I suggested that the Code should be perhaps be revised to give these persons several years to pay these taxes, with only a modest interest rate imposed for the privilege of making deferred payments, rather than requiring that the taxes all be paid in the year of discharge. ${ }^{119}$ The argument for a comparable deferred payment provision to be included in any repeal of the PSLF program debt forgiveness tax exemption is even stronger, given that these persons will generally have had only about 10 years to set aside funds in anticipation of these taxes, and moreover they would have had to do so out of relatively modest public service salaries, rather than having 20 or 25 years to build up a dedicated fund out of often 
larger private sector incomes to pay these taxes, as they have for the other incomebased repayment plans. Another possible mitigating statutory option here would be to allow those persons who have debts forgiven under the PSLF program to elect to pay those taxes over time in accordance with the terms of their prior loan repayment program, thereby giving them another 10 to 15 years or so to repay that tax debt at the original student loan interest rate. This approach of meshing the tax burden with the terms of their prior loan agreement would be equivalent to forgiving two-thirds to three-quarters of their loan debt without imposing any tax obligation at all, and then requiring repayment of the balance of the debt on the same terms as before. There would therefore be no "tax bomb;" no specific tax imposed in the year in which the remaining debts are (partially) forgiven. The borrower would then continue to make now much smaller loan repayments for another 10 to 15 years until any remaining debt is then forgiven, and then that forgiven debt would treated as taxable income in that year of final forgiveness as the tax laws now require.

There are of course numerous other possible compromises that one can envision to balance these competing legitimate interests of Direct Loan borrowers who have relied upon eventual debt forgiveness with the interests of the general 
taxpaying public. Whatever the resolution here, the sooner that these questions are

resolved the better for all concerned, given the virtual flood of applications for debt

forgiveness under the PSLF program that is almost upon us.

1 Homer R. Mitchell Endowed Professor in Commercial and Insurance Law, Dedman School of Law, Southern Methodist University. J.D., Yale Law School, Ph.D., University of Iowa.

2 Throughout this article I will I refer to the statutory Public Service Loan Forgiveness provisions as a "program" in accordance with commonly accepted parlance. In actuality, however, those provisions do not really establish a separate loan repayment "program," but only create a special accelerated debt forgiveness mechanism that complements the various federal student loan repayment plans.

3 College Cost Reduction and Access Act, Section 401 (2007) (amending the Higher Education Act) (codified at 20 U.S.C. Section 1087e(m)).

420 U.S.C. Section 1087e(m)(1). Federal Direct Loans have been made since 1994 under the Student Loan Reform Act of 1993. There are many other student loan programs, including the Federal Family Education Loan Program ("FFELP"), a program that was widely used prior to being discontinued in 2010, and under which the federal government guaranteed student loans made by private lenders, the Perkins federal loan program, and various other private, state and institutional loan programs. As of 2011 there were over $\$ 489$ billion of outstanding FFELP loans taken out by 23.8 million borrowers, much more than the $\$ 350$ billion of Direct Loans that were outstanding at that time (which has since grown to over $\$ 963$ billion of Direct Loans by 2017), and $\$ 8.3$ billion in outstanding Perkins loans made to 2.9 million borrowers. Federal Student Aid Portfolio Summary (2017), Federal Student Aid, Department of Education, available at http://studentaid.ed.gov/sa/about/data-center/student/portfolio. Loans made under any of these other loan programs are not eligible for debt forgiveness under the PSLF program. However, FFELP loans and Perkins loans can be later consolidated into Direct Loans which are eligible for PSLF program debt forgiveness, although any loan repayments made under those loan programs prior to such consolidation will not count towards the 10-year repayment period required for eventual debt forgiveness. A substantial number of borrowers who would otherwise be eligible for PSLF program debt forgiveness in 2017 or in the next few years after that after completing 10 years of public service employment will likely be precluded from program eligibility because their loan debts were incurred under the FFELP or Perkins programs and were not quickly consolidated into Direct Loans in a timely manner after their graduation.

$5 \mathrm{Id}$.

6 Id.at Section $1087 \mathrm{e}(\mathrm{m})(1)(\mathrm{B})$. The phrase "public service job" is very broadly defined at Section $1087 \mathrm{e}(\mathrm{m})(3)(\mathrm{B})$.

$7 \mathrm{Id}$. at Section $1087 \mathrm{e}(1)(\mathrm{A})$.

$8 \mathrm{Id}$. at Section $1087 \mathrm{e}(\mathrm{m})(2)$.

9 Internal Revenue Service Code, Section 108. 
10 See 34 CFR 685.219.

11 When the PSLF Program was enacted into law in 2007 the Congressional Budget Office estimated that "approximately 50,000 new borrowers each year would eventually be eligible for, and participate in, income-contingent loan forgiveness each year." College Cost Reduction Act of 2007, House Committee on Education and Labor Report, at p. 72. It is not entirely clear from this statement whether the CBO estimate was for the PSLF program alone, or for all borrowers participating in one or another of the income-contingent repayment plans, Id., although it appears likely that only estimated eventual PSLF program debt forgiveness utilization was included in this estimate. As I will later discuss herein this number is likely to be a substantial underestimate of eventual steady-state borrower participation.

12 The Trump Administration's first proposed Department of Education budget calls for ending the PSLF program as part of an overall attempt to reduce the DOE's budget by $\$ 9.2$ billion, or $13.6 \%$ of the current approved level of spending. Office of Management and Budget, Budget of the U.S. Government: A New Foundation for American Greatness, Fiscal Year 2018 (May 23, 2017) ("Trump Proposed Budget (2017)"); see also Emma Brown, Valerie Strauss, \& Danielle Douglas-Gabriel, “Trump's first full education budget: deep cuts to public school programs in pursuit of school choice,' Washington Post (May 17, 2017).

13 Trump Proposed Budget (2017), id., at 20.

14 Id.

15 The Trump Administration proposal leaves unclear whether this "current course of study" exception would apply to Direct Loans taken out to finance subsequent graduate school education by persons who were still completing their undergraduate programs as of July 1, 2018. Would a graduate degree that builds directly upon the knowledge obtained in an undergraduate program be regarded as part of the same "course of study" as that undergraduate program? As examples of this question, how about a Ph.D. degree obtained in the same field that was studied as an undergraduate, or a law degree obtained following graduation from a pre-law undergraduate program, or a medical school degree based upon the necessary predicate of a premed undergraduate curriculum? The proposal is also unclear as to whether it would apply to preJuly 1, 2018 FFELP or Perkins loans that were consolidated into Direct Loans after that date. See supra n. 4.

16 Calculating the net savings to the Treasury of retroactive termination of the PSLF program is a complicated undertaking, for several reasons. First of all, most persons who would utilize the program's debt forgiveness provisions are now enrolled in one or another federal income-based repayment plan, and will if the PSLF program is terminated still be able to eventually obtain debt forgiveness, but now after 20 or 25 years. So the amount of debt that each of those persons will have remaining for forgiveness after that longer repayment period would have to be estimated, requiring long-term projections of average salary histories, and then the present value of those forgiven debts would have to be offset from the 2017-2018 savings. In addition, the fact that those debts that would be forgiven after 20 or 25 years would be regarded as taxable income under current law will have to be taken into account, and will significantly reduce the size of this net offset from the savings from retroactive PSLF program termination. The net impact here of these alternative debt forgiveness options would be to reduce the taxpayer savings from PSLF program termination significantly, but exactly how much would be difficult to estimate. 
17 That forgiven debt would then be taxed at the marginal personal tax rate of the person whose debts are being forgiven, which would generally range from approximately $25 \%$ up to a maximum of $39.6 \%$. In addition, many states would also impose state income taxes on this forgiven debt once it is recognized as income for federal tax purposes. I have elsewhere estimated the overall average tax rate that will be imposed on forgiven debt under the federal income-based loan repayment programs at approximately 33\%. See generally Gregory Crespi, "Should We Defuse the 'Tax Bomb' Facing Lawyers Who are Enrolled in Income-Based Student Loan Repayment Plans?," 68 S. Car. L. Rev. 117 (2016), at 159-60 (“Crespi (2016)”). See also Gregory Crespi, "Will the Income-Based Repayment Program Enable Law Schools to Continue to provide 'Harvard-Style' Legal Education?," 67 SMU L. Rev. 51 (2014) ("Crespi (2014)"); Gregory Crespi, "The Obama Administration's New 'REPAYE” Plan for Student Loan Borrowers: Nor Much Help for Law Graduates," 35 Quin. L. Rev. 323 (2017) (“Crespi (2017)”). 18 See Public Service Loan Forgiveness Employment Certification Forms Report (2016): Federal Student Aid, Department of Education, available at http://studentaid.ed.gov/sa/about/data-center/student/portfolio ("ECF Report (2016)"). See also http://studentaid.ed.gov/sa/sites/default/files/public-service-employment-certification-form.pdf. 19 As of the fourth quarter of 2016 a total of 552,931 borrowers have had at least one employment certification application approved. ECF Report (2016), supra n. 18.

20 Id. $552,931-334,708=218,223$.

21 Id. $334,708-191,432=143,276$.

22 Id. $191,432-82,995=108,437$.

$23 \mathrm{Id}$.

24 Jason Delisle, "The Coming Public Service Loan Forgiveness Bonanza," Brookings Report (Sept. 22, 2016), at 2 ("Delisle (2016)"). See also Federal Student Loans: Education Could Do More to Help Ensure Borrowers Are Aware of Repayment and Forgiveness Options (August 2015), Government Accountability Office, GAO-15-663, at 27 (“GAO (2015)") (citing Bureau of Labor Statistics figures that $24.7 \%$ of US workers (32.5 million out of a total of 131.7 million US workers nationwide) were employed in PSLF-qualifying public service jobs). The Government Accountability Office has also estimated that as of June of 2016 approximately $24 \%$ of all Direct Loan borrowers were enrolled in one or another income-based loan repayment plan, and approximately $40 \%$ of all Direct Loan debts were being repaid through such plans. Federal Student Loans: Education Needs to Improve Its Income-Driven Repayment Plan Budget Estimates (November 2016), Government Accountability Office, GAO-17-22, at 8-9 ("GAO (2016)").

The statutory definition of "public service job" for the PSLF program is very broad. It includes all full-time employment by any level of government or by a qualifying Internal Revenue Code section 501( c)(3)/501(a) organization, or any of a number of listed public service activities done on a full-time basis for any employer whatsoever, without regard to whether that public service is the primary purpose of the employer. 20 U.S.C. S. $1087 \mathrm{e}(\mathrm{m})(\mathrm{B})$. The full text of the statutory "public service job" definition is important and is set forth below:

“(B) Public service job The term "public service job” means- 
(i) a full-time job in emergency management, government (excluding time served as a member of Congress), military service, public safety, law enforcement, public health (including nurses, nurse practitioners, nurses in a clinical setting, and full-time professionals engaged in health care practitioner occupations and health support occupations, as such terms are defined by the Bureau of Labor Statistics), public education, social work in a public child or family service agency, public interest law services (including prosecution or public defense or legal advocacy on behalf of low-income communities at a nonprofit organization), early childhood education (including licensed or regulated childcare, Head Start, and State funded prekindergarten), public service for individuals with disabilities, public service for the elderly, public library sciences, school-based library sciences and other school-based services, or at an organization that is described in section 501(c)(3) of title 26 and exempt from taxation under section 501(a) of such title; or

(ii) teaching as a full-time faculty member at a Tribal College or University as defined in section $1059 \mathrm{c}$ (b) of this title [20] and other faculty teaching in high-needs subject areas or areas of shortage (including nurse faculty, foreign language faculty, and part-time faculty at community colleges), as determined by the Secretary." Id.

The DOE by regulation has attempted to narrow PSLF program eligibility, but in a manner that is arguably inconsistent with the statute and subject to challenge. See Gregory Crespi, "The Public Service Loan Forgiveness Program: The Need for Better Eligibility Regulations," (June 6, 2017), available at: https://ssrn.com/abstract=2981893.

25 There were approximately 31.9 million Direct Loan borrowers as of the first quarter of 2017. Federal Student Aid Portfolio Summary (2017), Federal Student Aid, Department of Education, available at http://studentaid.ed.gov/sa/about/data-center/student/portfolio. If $24 \%$ of those Direct Loan borrowers are enrolled in income-based loan repayment plans, GAO (2016), id., that is 31.9 million $x 24 \%=7.66$ million people so enrolled. If one further assumes that $24.7 \%$ of those 7.66 million Direct Loan borrowers who are enrolled in income-based loan repayment plans work in qualifying public service positions, GAO (2015), id., that is 7.66 million x $24.7 \%$ $=1.89$ million public service employees who will very likely still have significant outstanding debt after 10 years of employment and who will therefore seek PSLF program loan forgiveness once they are eligible to do so.

For the long-term steady-state one would project that approximately $10 \%$ of those 1.89 million people will meet the 10-year employment requirement each year, 1.89 million $\mathrm{x} 10 \%=\underline{189,000}$ people each year, with those persons then replaced in the PSLF program "pipeline" by an approximately equal-size cohort of new employees also enrolled in income-based loan repayment plans. But it seems likely that given the relatively modest salaries paid by most public service positions a significantly higher proportion than $24 \%$ of those Direct Loan borrowers who work in public service positions will have enrolled in an income-based loan repayment plan, exceeding the overall average rate of enrollment for Direct Loan borrowers. In addition, the proportion of Direct Loan borrowers enrolling in income-based repayment plans has doubled just over the past three years, GAO (2016), id., at 8, and will likely continue to 
increase beyond the current $24 \%$ level given rising student loan debt levels and continuing relatively difficult employment prospects. So it is very possible that for these reasons that the eventual number of persons seeking PSLF program debt forgiveness each year might substantially exceed 200,000.

Approximately $76 \%$ of those Direct Loan borrowers who work in public service positions have not enrolled in an income-based loan repayment plan. This is a group of 31.9 million Direct Loan borrowers x $24.7 \%$ x $76 \%=5.99$ million people. These people are likely to have, on average, smaller initial loan debts than those persons who have enrolled in an income-based loan repayment plan. The large majority of these persons who have not enrolled in an income-based plan repayment plan will fully or almost fully repay their loan debts after 10 years of public service employment, and will therefore likely not seek PSLF program loan forgiveness even once they are eligible to do so, or may do so but will receive only very small amounts of debt forgiveness.

26 Jason Delisle estimates that the median debt load of those persons who have obtained one or more PSLF program employment certifications is over $\$ 60,000$, and that nearly $30 \%$ of those persons have a debt load of over $\$ 100,000$. Delisle (2016), supra $\mathrm{n}$. 24, at 4 . He also finds that $80 \%$ of borrowers who have obtained one or more PSLF program employment certifications have borrowed more than $\$ 30,000$, and concludes that "PSLF is really a de facto loan forgiveness program for graduate students...the program is dominated by students who attended graduate and professional school." Id. at 6. See also Barbara Hoblitzell, Ian Foss \& Dan Weigle, "Public Service Loan Forgiveness," (Powerpoint presentation, U.S. Department of Education, 2015 FSA Training Conference for Financial Aid Professionals (December 2015), available at http://fsaconferences.ed.gov/conferences/library/2015/2015FSAConfSession5.ppt) ("Hoblitzell et al (2015)").

27 Many law students will graduate with well over $\$ 150,000$ of combined law school and undergraduate student loan debt. For extended discussion of the magnitude of law school graduate debt loads see generally Crespi (2014), supra n. 17; Crespi (2016), supra n. 17, Crespi (2017), supra n. 17.

28 One might think that most doctors would earn substantial enough incomes during their first 10 years of medical practice that even payments of only $10 \%$ of their discretionary income as required under the PAYE or IBR plans would fully repay even quite substantial medical school loan debts before those persons qualified for debt forgiveness under the PSLF program.

However, many doctors will spend four years in residency at a relatively low salary at a hospital which qualifies as a public service employer, and then will serve up to another three years in a similarly low-paying qualifying internship. In that event, even after several later years of their making more substantial loan repayments out of a much larger income they would often still have substantial amounts of debt remaining to be forgiven under the program.

29 The Congressional Budget Office has estimated that the combination of capping the amount of debt that could be forgiven under the PSLF program to $\$ 57,000$ - as the Obama Administration proposed in 2014 - and eliminating the current cap on required monthly repayments to the amount owing under standard 10-year loan repayment terms - also recommended in 2014 by the Obama Administration - would save the government approximately $\$ 12.1$ billion over the 2015-2024 10-year period, approximately $\$ 1.2$ billion per 
year. Delisle (2016), supra n. 24, at 3. The savings would obviously be larger if the program were eliminated altogether.

30 Consider the circumstances of a typical person who graduates from an undergraduate program with the average $\$ 30,000$ of Direct Loan debt, at a typical 5\% overall annual interest rate, and has a spouse and child, and then takes a qualifying public service position with a $\$ 45,000$ starting salary, and then enrolls in the PAYE loan repayment plan. Under that plan this person will be required to make annual repayments of only $10 \%$ of the difference between their adjusted gross income and $150 \%$ of the poverty level wage for a person with a family of that size. For that person their annual payment obligation would be approximately $(\$ 45,000-\$ 30,000) \times 10 \%=$ $\$ 1,500$ per year. This would be just enough to meet the annual interest payments on their loan debt of $\$ 30,000 \times 5 \%=\$ 1,500$. In succeeding years, with modest annual raises and corresponding modest increases in their annual payment obligations under the PAYE plan, that person would begin to amortize their principal debt, but only by a few hundred dollars per year. After 10 years that person would still have on the order of $\$ 25,000$ or so of debt to be forgiven.

For an extended discussion of the financial details of the various federal income-based loan repayment plans, and of the tax consequences for borrowers of utilizing one of those plans without obtaining PSLF program loan forgiveness, see generally Crespi (2014), supra n. 17. The PSLF program is specifically addressed in that article at pages 99-101. For further discussion of the taxation issues raised by these income-based loan repayment programs, and discussion of the impacts Revised Pay As You Earn plan, the newest addition to the menu of subsidized loan repayment options, upon law school graduates, see also Crespi (2016), supra $\mathrm{n}$. 17, Crespi (2017), supra n. 17.

31 If one annualizes the benefits of $\$ 25,000$ in forgiven debt after 10 years over a 10-year period at a $5 \%$ annual discount rate, this comes to approximately $\$ 1,987 /$ year. Assuming that the typical public service worker is in a $25 \%$ combined marginal federal and state income tax bracket, this would be equivalent to approximately $\$ 1,987 \times 1.33=\$ 2,642 /$ year in additional before-tax income.

$32 \$ 2,642 / \$ 45,000=0.0587$. See supra n. 30 .

33 Consider the circumstances of a typical person who graduates from law school with a combined undergraduate and law school Direct Loan debt load of \$150,000, at a typical 6\% overall annual interest rate that reflects the higher rate charged graduate school borrowers compared to undergraduates. Assume again that this person also has a spouse and child, and then takes a qualifying public service position as an attorney with a $\$ 55,000$ starting salary, and then enrolls in the PAYE loan repayment plan. Under that plan this person will be required to make annual repayments of only $10 \%$ of the difference between their adjusted gross income and $150 \%$ of the poverty level wage for a person with a family of that size. For that person their annual payment obligation would be approximately $(\$ 55,000-\$ 30,000) \times 10 \%=\$ 2,500$ per year. This would be far short of the amount needed just enough to meet the annual interest payments on their loan debt of $\$ 150,000 \times 6 \%=\$ 9,000$. Their debt would therefore increase by $\$ 9,000-\$ 2,500=\$ 6,500$ that first year. In succeeding years, with modest annual raises and corresponding modest increases in their annual payment obligations under the PAYE plan, the amount of unpaid interest that would accrue would gradually reduce, but the negative 
amortization would likely persist for the entire 10 year period, leading to a total principal plus accrued interest debt of over $\$ 200,000$ at the time of debt forgiveness.

For an extended discussion of the financial details of the various federal income-based loan repayment plans, and of the tax consequences for borrowers of utilizing one of those plans without obtaining PSLF program loan forgiveness, see also Crespi (2014), supra n. 17, Crespi (2017), supra n. 17.

$34 \$ 200,000$ of forgiven debt is eight times as large as the $\$ 25,000$ of forgiven debt for a typical undergraduate borrower, see supra $\mathrm{n}$. 30. If one annualizes the benefits of $\$ 200,000$ in forgiven debt after 10 years over a 10 -year period at a $5 \%$ annual discount rate, this comes to approximately $\$ 15,896 /$ year. Assuming that the typical law public service worker is also in a $25 \%$ combined marginal federal and state income tax bracket, this would be equivalent to approximately $\$ 15,896$ x $1.33=\$ 21,142 /$ year in additional before-tax income.

$35 \$ 21,142 / \$ 55,000=0.3844$. See supra $\mathrm{n} .33$.

36 This medical school graduate with similar initial debt and family circumstances will be in essentially the same position as the law school; graduate discussed above, supra n. 33, except for the fact that they would be likely to receive a substantial salary increase after completion of their internship for the last three years of their 10-year public service period, perhaps even enough to repay some of the accrued interest from the seven years of pronounced negative amortization. 37 Jason Delisle argues that the fact that the PSLF program will disproportionately benefit highdebt graduate school borrowers is not only improperly regressive in its incidence but will also distort incentives to attend graduate school and encourage graduate schools to raise their tuitions. See Deslisle (2016), supra n. 24, at 6-7. There has also been criticism of law schools encouraging their students to later to utilize the PSLF program as an indirect means of making those students less resistant to tuition increases. See Student Loan Planner LLC, "Georgetown Law School PSLF Abuse Shows Why Program Will End” (Dec. 19, 2016), available at https://www.studentloanplanner.com/georgetown-law-school-pslf-abuse/.

On the other hand, law school graduates and doctors who enter public service positions rather than take private sector positions will on average make much larger financial sacrifices than will persons who enter public service with only undergraduate degrees, both in absolute dollar terms and in terms of the proportion of their alternative private sector salary forgone. Given this fact, a significantly larger financial inducement may be necessary to adequately encourage lawyers and doctors to enter public service than to induce persons with only undergraduate degrees to do so. This need for providing a stronger financial inducement for persons with financially more attractive alternatives to public service may justify the conceded regressivity and perverse incentive impacts upon borrows and graduate schools of the way that the debt forgiveness benefits of the PSLF program are allocated. There is room for reasonable disagreement here. 38 An even more difficult question is posed by Direct Loans taken out after 1994 and before October 1, 2007. Those Direct Loans may be forgiven under the terms of the PSLF program, but there is no reference made in the MPN that was executed for those loans to the PSLF program since that program had not yet been enacted. Whether these loans would provide borrowers with contractual protection against subsequent legislation curtailing PSLF program debt forgiveness 
rights to the same extent as would post-October 1, 2007 Direct Loans that reference the PSLF program is a hard question to answer; I suspect that they would not do so.

39 See https://studentloans.gov/MyDirectLoan.

40 See Internal Revenue Service Code, Section 108.

41 The current DOE PSLF program regulations at 34 CFR Section 685.219(b) broadly define what organizations will qualify as "public service organizations" whose employees may qualify for PSLF program debt forgiveness. However, despite previously certifying for several prospective program applicants that their employment by the American Bar Association ("ABA") would qualify as employment by a public service organization, the DOE under the Obama Administration (through FedLoan Servicing, an organization to whom the DOE has delegated PSLF program administrative responsibilities, [cite]) later took the position that ABA employment will not so qualify, and the DOE has since been sued by the ABA in the United States District Court for the District of Columbia in an attempt to reverse this new ruling [cite]. The DOE has also recently taken a similar position with regard to American Civil Liberties Union ("ACLU") employment, despite their also having previously certified ACLU employment as qualifying for the PSLF program, [cite] and with regard to the American Immigration Lawyers Association ("AILA") employment, again despite their also having previously certified AILA employment as qualifying. [cite]

42 Gregory Crespi, [cite]

43 Which I believe would also then be permitted, although there are substantive due process concerns that can be raised. See Part V herein.

44 I have included the selective use of large bold font that is utilized by the Master Promissory Note.

45 See Internal Revenue Code, Section 108.

46 College Cost Reduction Act of 2007, House Report together with Minority Views, 110th Cong., Report 110-210, at 72 (2007).

47 As of the fourth quarter of 2016 a total of 552,931 borrowers have had at least one employment certification application approved. ECF Report (2016), supra $\mathrm{n} .18$.

48 See supra n. 20.

49 See supra $\mathrm{n}$. 3. Of these certifications, approximately $62 \%$ of the applicants were employed by a governmental body, and $38 \%$ by a qualifying Section 501(c)(3) organization. Hoblitzell et al (2015), supra n. 26, at 23. Approximately $70 \%$ of the applications for certification were granted, $i d$. at 24 , and the remainder were denied either because the employer did not qualify, the loans involved were not eligible for forgiveness, or there was missing and/or incorrect information on the application. Id. at 25.

50 Delisle (2016), supra n. 24, at 2.

51 Undergraduate borrowers are only permitted to borrow $\$ 31,000$ over five years of education (\$57,500 in the case of independent students). Delisle (2016), supra n. 24, at 6.

52 Id. at 5 (drawing upon Hoblitzell et al (2015), supra n. 26, at 28).

53 See GAO (2015), supra n. 24, at 30-31.

54 [cite]

55 [cite]

56 Delisle (2016), supra n. 24, at 3. 
57 Federal Student Aid Portfolio Summary (2017), Federal Student Aid, Department of Education, available at http://studentaid.ed.gov/sa/about/data-center/student/portfolio (24.9 million Direct Loan borrowers have taken out their loans after 2007, and 7.0 million additional Direct Loan borrowers had outstanding loans as of fiscal year 2007). In addition, as of 2011 there were 23.8 million persons with outstanding FFELP loans under that loan program that was discontinued in 2010, and 2.9 million persons with outstanding Perkins loans, $i d$., and some significant proportion of these persons have or will later consolidate those loans into Direct Loans that are eligible for PSLF program debt forgiveness. See supra n. 4.

58 Delisle (2016), supra n. 24, at 4.

59 [cite]

60 See supra n. 26.

61 As the Trump Administration is already attempting to impose with its recent DOE budget proposal. See supra n. 12.

62 See supra n. 21.

63 See supra n. 20.

64 See Federal Student Aid Portfolio Summary (2017), Federal Student Aid, Department of Education, available at http://studentaid.ed.gov/sa/about/data-center/student/portfolio.

$65 \mathrm{Id}$.

$66 \mathrm{Id}$.

67 These recent figures, showing that the number of persons filing annually for annual employment certifications by 2016 is now over 10\% as large as the number of annual new Direct Loan borrowers, suggests that the proportion of the approximately one-quarter of Direct Loan borrowers who will take public service positions who will eventually seek PSLF program loan forgiveness, is now in the neighborhood of $40 \%$, since $10 \% / 25 \%=40 \%$.

68 See supra n. 25.

69 Given that prior employment certifications are not a requirement for debt forgiveness eligibility, and given that an estimated one-quarter of all employment would qualify for the PSLF program, and given the rapidly rising proportion of Direct Loan borrowers enrolling in income-based loan repayment plans, this 200,000 number may well be a conservative underestimate of the number of people who will annually seek debt forgiveness.

70 Delisle (2016), supra n. 24, at [cite].

71 Given that there is a "long right tail" of law school or medical school Direct Loan borrowers with very large loan debts, the average amount of initial loan debt owed by persons who will eventually obtain PSLF program debt forgiveness may well exceed the estimated median debt load of $\$ 60,000$.

72 Consider, for example, a Direct Loan borrower with a $\$ 60,000$ initial loan debt at a typical average annual interest rate of $6 \%$, and with a spouse and child, who takes a public service position starting at a $\$ 50,000$ annual salary. Under the PAYE plan that person would have to make annual loan repayments of $10 \%$ of their disposable income, approximately $(\$ 60,000-$ $30,000) \times .10=\$ 3,000$. This would be somewhat less than the $\$ 60,000 \times .06=\$ 3,600$ annual interest charge on their loan, leading to a $\$ 600$ annual increase in their debt. Over the years with modest annual salary increases that person's loan repayments would correspondingly increase somewhat, gradually shifting them to being able to slightly amortize their loan debt. After 10 
years that person's remaining unpaid debt would likely be quite close in size to their initial debt. For a high-debt law school of medical school borrower, however, there would be substantial negative amortization throughout most or all of the 10-year period, leading to a forgiven debt well in excess of the original substantial loan amount.

73 [cite]

74 Given that there is a "long right tail" of law school or medical school Direct Loan borrowers with very large loan debts, which will then grow substantially over the next 10 years due to negative amortization of interest charges, the average amount of debt forgiven by persons who will eventually obtain PSLF program debt forgiveness may well exceed the estimated average $\$ 60,000$ amount of forgiven debt.

$75200,000 \times \$ 60,000=\$ 12,000,000,000$.

76 See supra n. 25.

77 [cite]

$782,000,000 \times .0 .15=300,000$.

$79300,000 \times \$ 60,000=\$ 18,000,000,000$.

80 Perry v. United States, 294 U.S. 330, 351 (1935).

8128 U.S.C. Section 1491(a)(1).

82 See the several MPN provisions referring to "this MPN" noted above at pages of the main text.

83 "With regard to incorporating a description of the public service loan forgiveness benefit in the MPN, the Department is already taking steps to refer to the program in the MPN and other program documents. However, the MPN will continue to state, as it currently does, that the terms and conditions of the loans are subject to the HEA as amended in accordance with the effective date of those amendments. Although there is no history in the program of Congress elimination or reducing a borrower benefit, the Department does not believe that a reference to the public loan forgiveness program in the MPN would provide the borrower with a contractual right to the benefit should Congress take action to eliminate that benefit from the HEA as of a particular effective date." Department of Education, Federal Perkins Loan Program, Federal Family Education Loan Program, and William D. Ford Federal Direct Loan Program: Final Rule, 73 Fed. Reg. 63242 (Oct. 23, 2008)

84 "[T] the qualifying terms and conditions ... being modified prior to the satisfactionof the 120-payment requirement. In fact, the MPN provides clear notice that any amendments to the HEA will be incorporated into the terms of the MPN." "AccessLex Institute, "Policy Analysis: Impact of Potential Changes to Public Service Loan Forgiveness Program," available at https://www.accesslex.org/index.php/policy-analysis-impact-of-potential-changes-to-publicservice-loan-forgiveness-program (July, 2016).

85 Centex Corp. v. United States, 38 F.3d 1283 (Fed. Cir. 2005).

86 Id. at 1304.

87 [cite]

88 For example, consider a law school graduate who graduated with a $\$ 150,000$ combined undergraduate and graduate student debt load at an overall average $7 \%$ annual interest rate on their loans, not an unusual amount of debt at this time nor an unusual average interest rate, and who then took a qualifying $\$ 50,000 /$ year public service job and enrolled in the PAYE loan 
repayment plan. If one assumes a typical disposable income of approximately $\$ 30,000 /$ year this person would then make approximately only $\$ 3,000$ /year in loan repayments under the PAYE plan. This person would then owe approximately $\$ 225,000$ after 10 years of loan repayments, due to the significant negative amortization (without capitalization of the unpaid interest) of their $\$ 10,500$ annual interest payment obligations on their loans. If the PSLF program was statutorily abolished retroactively to require continuing repayment of that sum at a 7\% interest rate, rather than forgiving that debt, this additional burden of $\$ 225,000$ of debt now to be repaid would be economically equivalent to a VERY large increase in the initial interest rate charged on the original $\$ 150,000$ of loans! Even only the lesser change of removing the tax exemption for debt forgiven under the PSLF program would impose on that graduate a large one-time tax bill of approximately $\$ 75,000$, a significant burden indeed for most persons who have worked for at least 10 years in modestly compensated public service positions.

89 See, e.g., United States v. Carlton, 515 U.S. 26 (1994).

90 See Restatement (Second) of Contracts, Section 90.

$91 \mathrm{Id}$.

92 "[W]hen the United States enters into contract relations, its rights and duties therein are governed generally by the law applicable to contracts between private parties." Mobil Oil Exploration and Producing Southesast, Inc. v. U.S., 530 U.S. 604, 607(2000).

93 OPM v. Richmond, 496 U.S. 414, 429-20 (1990).

94 "The principle is one of the prevention of... unfair surprise." Uniform Commercial Code Section 2-302, Official Comment 1.

95 See generally Williams v. Walker Thomas, 350 F.2d 445 (D.C. Cir. 1965).

96 See, e.g., United States v. Carlton, 515 U.S. 26 (1994).

97 County of Mobile v. Kimball, 102 U.S. 691, 703 (1880).

$98 \mathrm{Id}$. at 34. "[T] ax legislation is not a promise, and a taxpayer has no vested right in the Internal Revenue Code." Id.

99 See, e.g., United States v. Darusmont, 449 U.S. 292, 299-300 (1981).

100 Nichols v. Coolidge, 274 U.S. 531 (1927).

101 United States v. Carlton, supra n. 89, at 34.

102 See supra n. 4.

103 See, e.g., United States v. Carlton, supra n. 89.

104 "[N]or shall private property be taken...without just compensation." U.S. Constitution, Amendment V.

105 "No State shall...pass any...Law impairing the Obligation of Contracts..." U.S.

Constitution, Article I, section 10, clause 1.

106 Elmer W. Roller, "The Impairment of Contractual Obligations and Vested Rights," 6 Marq. L. Rev. 129 (1922).

107 " $[\mathrm{N}]$ or shall private property be taken... without just compensation." U.S. Constitution, Amendment V.

108 United States Trust Co. v. New Jersey, 431 U.S. 1, 19 n. 16 (1977) (“Contract rights are a form of property and as such may be taken...provided that just compensation is paid."); see also Lynch v. United States, 292 U.S. 571, 579 (1934) ("Valid contracts are property, whether the obligor be a private individual, a municipality, a State, or the United States.")

109 Bowen v. POSSE, 477 U.S. 41(1986). 
$110 \mathrm{Id}$. at 52.

$111 \mathrm{Id}$. at 55.

112 Id. at 52 (citing Merrion v. Jicarilla Apache Tribe, 455 U.S. 130, 148 (1982)).

113 Id. at 55 (citing Lynch v. United States, 292 U.S. 571 (1934)).

114 The DOE and the AccessLex Institute are of the same opinion here. See nn. 83-84 and the associated text.

115 See supra $\mathrm{n} .12$.

116 See Crespi (2016), supra $n$. 17, for extensive discussion of the comparable tax bomb that will be imposed by the PAYE plan and by the Income-Based Repayment plan on high-debt law school graduates when millions of Direct Loan borrowers will have their remaining debts forgiven under one or another of those plans after either 20 or 25 years of making repayments.

117 See supra n. 30.

118 See supra n. 31.

119 Crespi (2016), supra n. 17, at 196-97. 